\title{
What Drives Executive Stock Option Backdating?
}

\author{
Chris Veld and Betty H.T. Wu*
}

Forthcoming, Journal of Business Finance \& Accounting, 2014

We study motives for executive stock option backdating, the practice of changing the grant dates of current options to dates in the past using hindsight. We find that smaller, younger, and less profitable firms tend to be heavier involved in backdating. These results are consistent with the retention hypothesis. In line with the incentive hypothesis, we find that backdating occurs more for options that are out-of-the-money. We derive some evidence for the agency hypothesis, in the sense that backdating companies have a larger percentage of inside directors. However, contrary to this hypothesis, we conclude that backdating firms have better protection for minority shareholders compared to firms that do not backdate.

\section{JEL: G3}

Keywords: executive compensation; stock option grants; backdating; corporate governance

\footnotetext{
* The first author is at Monash University. The second author is at University of Glasgow Adam Smith Business School. The authors would like to thank Steven Young, Associate Editor, and an anonymous referee for very insightful comments that significantly improved the paper. We are indebted to Riccardo Calcagno, Enrico Perotti, Ludovic Phalippou, and Zacharias Sautner for constructive comments and advice. We also thank participants at the 2013 British Accounting and Finance Association (the Scottish Area Group) Annual Conference, the 2012 Capital Markets Conference, the 2011 NTU International Conference on Economics, Finance and Accounting, the 2009 Financial Management Association Annual European Conference, the 2009 Midwest Financial Association Annual Meeting, the Final Conference of European Corporate Governance Training Network, the 2008 Doctoral Session of European Finance Association Annual Meeting and seminar participants in the University of Glasgow, Korea University Business School, the Yonsei School of Business, the SKK GSB, the Finance Group at University of Amsterdam, and the Tinbergen Institute for useful comments and suggestions. We thank Annie H.L. Wu for assistance in the earlier version of the paper. Lastly, Betty $\mathrm{Wu}$ is grateful to the European Corporate Governance Training Network for financial support.
}

Address for correspondence: Betty Wu, Adam Smith Business School, Glasgow G12 8QQ, Scotland, United Kingdom. e-mail: Betty.Wu@glasgow.ac.uk 


\section{Introduction}

In December 2006, shareholders of the Apple Company were relieved to find that the iconic chief executive, Steve Jobs, was largely exonerated from blame in the backdating of employee stock options of the company. Option backdating is the practice of using hindsight to change the grant dates of current options to dates in the past. Because of accounting conventions and tax considerations, employee stock options are generally granted at-the-money, i.e., the exercise price is set equal to the market price. If options are backdated, in fact the exercise price is lowered by choosing a date in the past with a lower stock price. This practice is not illegal on itself, as long as it is revealed to shareholders, but it can be controversial as the Apple case shows.

Yermack (1997), the precursor of the literature on option backdating, identified a pattern of abnormal stock price returns around executive stock option grants in the sense that there were abnormally high returns immediately after these options were granted. Other than pure luck and/or the ability to forecast stock prices, firms' timing of option grants or firm-related announcements, or "springloading", is the most likely explanation for these abnormal returns. Several subsequent studies (e.g., Aboody and Kasznik, 2000; Chauvin and Shenoy, 2001; Lie, 2005; Heron and Lie, 2007) further show that stock returns are abnormally low before the grant dates. ${ }^{1}$ Lie (2005) and Heron and Lie (2007) argue that the stock options in question are more likely backdated and that the firms are not likely timing grants and/or backdating information flow to the market. In other words, with hindsight, the grant dates of current options are changed to dates with lower strike prices.

\footnotetext{
${ }^{1}$ The combination of low abnormal returns before the backdating and high abnormal returns after is often referred to as the "V"-shape for option backdating.
} 
Heron and Lie (2009) estimate that $13.6 \%$ of all top executive (CEO) option grants from 1996 to 2005 are backdated or otherwise manipulated. This estimate is $18.9 \%$ for unscheduled at-the-money grants, but it has decreased significantly since the passage of the Sarbanes-Oxley Act of 2002 (SOX). ${ }^{2}$ At the firm level, $29.2 \%$ of their firms are estimated to have backdated grants, though not all grants have been backdated.

Firms often argue that option backdating is essential to restore incentives and to retain talented executives. Both arguments are backed up by empirical research: for example, Fang (2010) finds evidence for the retention explanation, and the research of Gao and Mahmudi (2011) supports the incentive hypothesis. However, others have argued that by resetting existing option grants to a date with a favourable price, executives are in fact rewarded for poor performance, which can be viewed as an example of managerial entrenchment or rent-seeking. Studies of e.g. Collins et al. (2009) and Bizjak et al. (2009) relate option backdating to inferior corporate governance, also known as the agency hypothesis. The anticipation of possible option backdating is detrimental to managerial incentives, i.e., executives profit from upside risk (when options become in-the-money) while enjoying protection from downside risk (when out-of-the-money options are backdated). The empirical findings of studies that test the agency hypothesis go in different directions: Collins et al. (2009) find that option backdating results from weak governance, whereas Bizjak et al. (2009) do not find such a relation.

\footnotetext{
${ }^{2}$ On August 29, 2002, this Act was passed to address issues such as independent auditors, corporate governance, internal control assessment, and financial disclosure. Among others, firms are required to report their executive stock option grants within two business days to the Securities and Exchange Commission (SEC), which makes this information available to the public within one day. Previously, reports of such grants were not due until 45 days after the firm's fiscal year-end and were to be announced to the shareholders in the proxy statement for the following year's annual meeting.
} 
Despite the fact that there are a number of empirical studies on the causes of backdating, there is no conclusive evidence as of yet. For example, the literature is divided on whether or not option backdating is associated with weak governance. In addition, the empirical research tends to be fragmented with different studies focusing on different aspects of the cause for backdating. The goal of this paper, therefore, is to compare the competing explanations for backdating, i.e. incentive alignment, retention, and agency considerations. By combining proxies for all three different hypotheses in one cross-section and by considering different variables for the agency hypothesis, we aim to present an extensive analysis comparing the relative strength of each of these three explanations.

We employ a sample of 6,830 stock option grants issued to the top executives in the Standard \& Poor's (S\&P) 1500 companies between 1999 and 2007. Following Heron and Lie (2009), we estimate the likelihood of option backdating on the basis of the assumption that, in the absence of backdating, the distributions of stock price returns during the month immediately before/after the grants should be similar. Namely, significant (positive) abnormal return differences imply the existence of some kind of grant date manipulation. We calculate abnormal returns as the difference between the stock returns of the granting firm and the returns predicted by the Fama-French three-factor model. We primarily focus on grants whose abnormal return differences rank above $90 \%$ in the sample distribution.

In terms of the determinants, we use a linear probit model to estimate the likelihood of option backdating. Overall, we find strong evidence for the retention hypothesis because smaller, younger and less profitable firms tend to backdate more than other firms. As expected, the likelihood for backdating is higher for high-technology firms because of the more competitive labour market. The incentive hypothesis is also confirmed because 
backdating occurs more for options that are out-of-the-money. Despite the negative press that employee stock option backdatings often receive, our evidence does not support the agency hypothesis. In particular, we find that companies that backdate options have better protection for minority shareholders compared to companies that do not backdate. Therefore, it seems that employee stock option backdating is associated with better rather than with weak corporate governance. The only minor confirmation that we find for the agency hypothesis is the fact that option backdating companies have a larger percentage of inside directors on the board. This result confirms an earlier finding by Collins et al. (2009). Our findings still hold after controlling for industry and year fixed effects.

Although we find evidence that incentive-realignment considerations influence the decision to backdate options, whether the intention to engage in option backdating is materialized ex-post matters more. In addition to the legal ramifications, this question has important implications for shareholders. ${ }^{3}$ For that purpose, we investigate the relation between option backdating and subsequent firm performance. We use the treatment-effects model and find no relation between backdating and operating performance after controlling for drivers for backdating. In other words, option backdating is not capable of repairing mismatched incentives and is not detrimental, either. The selection attributes resemble the option repricing mechanism. Again, there is no evidence for ineffective governance or executive entrenchment. Collectively, these findings suggest that firms engage in option backdating more for retaining valuable employees and less for restoring incentives effectively. Besides, there is no evidence that non- and backdating firms perform differently in the long-term market performance.

\footnotetext{
${ }^{3}$ For instance, Narayanan et al. (2007) and Bernile and Jarrell (2009) document negative abnormal stock returns around public disclosure of backdating-related practices despite no direct linkage to cash flow consequences.
} 
The remainder of this paper is organized as follows. Section 2 describes the related literature and develops the hypothesis. Section 3 describes the sample construction, data collection, and methodology applied for estimation. Section 4 describes the estimation and testing results. Section 5 summarizes the findings and presents concluding remarks.

\section{Literature Review and Hypotheses}

\subsection{Option Repricing and Option Backdating}

The terms of stock options are set at the time of the grant, but they are sometimes subject to changes before these options expire. The most common such change is option repricing, i.e., the strike prices are lowered after a decline in stock price. Usually, the new strike prices are $30 \%-40 \%$ lower than the old ones, often with an extension of the option maturity. Formally, option repricing is executed either by replacing the existing options with new grants at more favourable terms or by rewriting the terms of the existing option grants (Chidambaran and Prabhala, 2003). Option repricing was commonly used among firms in the 1990s. Like option backdating, the repricing phenomenon has received considerable attention in the press and was criticized by outsiders because it is viewed as an example of managerial entrenchment. Facing the intense pressure from active institutional investors, the regulatory agency, the Financial Accounting Standards Board (FASB) was forced to take action in 1998 and required firms to expense the estimated value of the repriced grants. Since then, the practice of repricing largely disappeared (Carter and Lynch, 2003). For example, the number of all senior executives having options repriced dropped 70\% in 1999 (65\% for CEOs). ${ }^{4}$

\footnotetext{
${ }^{4}$ Data source: the Compustat (ExecuComp).
} 
Option backdating shares similar features with option repricing. An option is viewed as backdated when its grant date is set "retroactively", to a date with a more favourable stock price, before a rise in stock price, usually at the bottom of a steep drop. Therefore, the similarity between option repricing and option backdating mainly emerges from the fact that, for both practices, the strike price of a grant is reset to be significantly lower. However, the two approaches use different "tools": option repricing resets the strikes directly whereas option backdating resets the grant date, which indirectly changes the strikes. These shared characteristics suggest that the typical explanations for option repricing seem to provide a plausible rationale for option backdating.

\subsection{Hypotheses}

\subsubsection{The Retention Hypothesis}

Firms, particularly in the high-technology industry, often explicitly state that retaining talented executives is the main reason for repricing option grants. Typically, executives hold many unvested option grants, which are forfeited upon voluntary departure. Hence, these options maintain their retentive power as long as they are not too much out-of-the-money (Scholes, 1991; Mehran and Yermack, 1997). Without repricing, the costs of unexpected executive departures can be substantial. Empirical studies show that option repricing is associated with lower subsequent voluntary executive turnover (Carter and Lynch, 2001; Chidambaran and Prabhala, 2003; Chen, 2004).

We hypothesize that option backdating, just like option repricing, serves the purpose of retaining valuable executives. Fang (2010) uses a sample of 117 backdating firms identified by the Wall Street Journal (with 344 pair-matched firm-year observations) and finds that 
younger and quickly growing firms in a more competitive labor market tend to backdate options. She further links backdating to performance, and the univariate analysis in her paper shows that these firms outperform their matched counterparts before and after backdating. She argues that these results provide evidence that option backdating is used mainly for retaining valuable employees, making it less subject to agency issues. In addition, Armstrong and Larcker (2009) provide some behavioral explanations, ${ }^{5}$ other than a tax-based rationale (Dhaliwal et al., 2009), for this practice. Formally, our Retention Hypothesis is as follows:

\section{H1: Firms backdate options to retain talented executives.}

We use the following proxies to test the Retention Hypothesis:

- Firm Size and Firm Age: we measure firm size by using the market value of a firm's equity. We estimate firm age by calculating the difference between the first year in which the firm has data in Compustat and the option grant year. Consistent with the option repricing literature (e.g., Chance et al., 2000; Brenner et al., 2000; Carter and Lynch, 2001; Chidambaran and Prabhala, 2003), we expect that smaller and younger firms have a higher tendency for option backdating for retention purposes.

- Growth Opportunity: to estimate growth opportunity, we first calculate the market value of assets, i.e., the book value of assets plus the market value of common stock less the sum of book value of common equity and balance sheet deferred taxes. Then, we divide this market value of assets by the book value (the so-called $\mathrm{Q}$ ratio). When a firm faces high growth prospects, it is vital to attract and retain the top

\footnotetext{
${ }^{5}$ For instance, they argue that backdating can be the result of social influences or a standard human resources process to successfully attract talent to the firm. Executives may also view the benefits from backdating as some type of personal entitlement.
} 
management talent. Therefore, we expect a higher growth opportunity to increase the propensity for option backdating.

- Profitability: return on assets is a ratio of EBIT (Earnings Before Interest and Taxes) to total assets. Prior studies suggest that option repricing is associated with poor prior performance (Carter and Lynch, 2001; Chidambaran and Prabhala, 2003). For retention purposes, we hypothesize that firms with poor prior performance tend to backdate options.

- Industry: to capture the industry-specific effects, we follow Chidambaran and Prabhala (2003) and create three industry dummy variables. ${ }^{6}$ In addition, we use 2-digit SIC codes to control for the industry fixed effects more generally. Chidambaran and Prabhala (2003) find that firms in the technology, trade and service industries tend to reprice options. Carter and Lynch (2001) argue that high-technology firms are more likely to be situated in a competitive labour market and thus face higher managerial turnover. They show that option repricing is an effective tool to recruit and retain talent. Chance et al. (2000) and Brenner et al. (2000) do not find such discrepancies across industries. We hypothesize that, for retention purposes, executive stock options are more likely to be backdated in the high-technology industry.

- Share Ownership: we estimate equity ownership as the ratio of shares owned by an executive to total shares outstanding of the firm. Equity ownership can be viewed as a measure for managerial entrenchment (Morck et al., 1988). For retention purposes,

\footnotetext{
${ }^{6}$ A technology industry dummy includes the Computer \& Electronics Parts (group 8), Software \& Technology (group 17), and Biotech (group 18) industries. A services industry dummy indicates the services industry (group 15). A trade industry dummy contains the Wholesale (group 13) and Retail (group 14) industries.
} 
we expect that executives with lower equity ownership (who are thus less entrenched) are more likely to have their options backdated.

\subsubsection{The Incentive Hypothesis}

Because stock options are generally granted at-the-money, the sensitivities of option values to stock price movements, and hence the managerial incentives, would vary over time. Deep-in-the-money options enhance managerial incentives because option values move nearly one-for-one with stock prices. In contrast, deep out-of-the-money options make option values insensitive to stock price fluctuations, resulting in weak incentives. Since these options are no longer able to render any material incentives, revising the strike price downward is necessary to restore managerial incentives. However, the very anticipation of option repricing can be detrimental to managerial incentives. By resetting the strike price, executives are in fact rewarded for poor performance, which contradicts the original purpose of option grants. This repricing possibility reduces managers' ex-ante incentives to perform because they are protected from downside risk. Acharya et al. (2000) employ an agency-theoretic model of compensation contracting and examine the incentive effects of option repricing. They show that although the anticipation of resetting can negatively affect initial incentives, resetting can still be important and enhance value for compensation contracts, even ex-ante. Repricing is almost always optimal in some contingencies. The equilibrium hinges on the tradeoff between these two opposing incentive effects.

Chidambaran and Prabhala (2003) find that higher executive option holdings (not share ownership) are associated with higher option repricing while Chen (2004) finds that higher CEO share ownership (not option holdings) decreases the likelihood of adopting repricing 
restrictions. Ex-post, Sauer and Sautner (2008) find that performance improves significantly after repricing.

Similar to the repricing literature, Gao and Mahmudi (2011) argue that backdating can be a form of efficient contracting for risk-averse and under-diversified executives. They find that backdating is associated with lower overall pay and better managerial incentive structures. Formally, our Incentive Hypothesis is described as follows:

H2: Firms backdate options in order to create better incentives for their executives.

We use the following proxies to test the Incentive Hypothesis:

- Option Holdings: the option grant ratio is calculated by using option grant value (using the Black-Scholes method) divided by total compensation in the current year. ${ }^{7}$ As described before, equity-based compensation is designed to address the conflict of interest between ownership and control by aligning the interests of both parties (Jensen and Meckling, 1976). When executives have large option holdings relative to their direct equity ownership, the need for option repricing is higher because of the misalignment in incentives when facing downside risk and/or simply because it is valuable to do so (Chidambaran and Prabhala, 2003). Therefore, we hypothesize that executive option holdings are positively related to backdating.

- Out-of-Moneyness: the literature on option repricing (e.g., Carter and Lynch, 2001; Chidambaran and Prabhala, 2003) suggests that option repricing is positively associated with the out-of-moneyness (OOM) of existing executive option

\footnotetext{
7 These values are reported by ExecuComp. As a proxy for option grant value, we use the data item “OPTION_AWARDS_BLK_VALUE” which adopts a modified Black-Scholes option valuation methodology. The modification is based on the fact that employee stock options are usually exercised early. For this reason they use $70 \%$ of the option's stated life in the Black-Scholes calculation instead of the stated life of the option. See Veld (2003) for a discussion on the effects of early exercise on employee stock options.
} 
portfolios for the purpose of restoring weak incentives. Instead of applying the full-information method (FI), the typical method in the repricing literature, ${ }^{8}$ which might require up to 10 years of historical proxy statements to perfectly identify the required characteristics of CEO option portfolios for Black and Scholes valuations, we follow Core and Guay's (2002) one-year approximation method (OA) which requires information from the most recent proxy statement only. They argue that the OA method explains $99 \%$ of the actual variation in option portfolio values and sensitivities. This has been widely adopted by studies that examine managerial option portfolio sensitivities (e.g., Brockman et al., 2010). ${ }^{9}$

More specifically, we measure how the subsequent price change affects the in-the-money option value at the previous fiscal year-end (FYE). It is defined as follows,

$$
\text { Out }- \text { of }- \text { Moneyness }(O O M)=\frac{-\sum Q_{i} *\left(P^{\prime}-P_{F Y E}\right)}{\text { OptionValue }_{F Y E}}
$$

where $\sum \mathrm{Q}_{\mathrm{i}}$ is the aggregate number of unexercised (vested and unvested) options, OptionValue $_{F Y E}$ is the estimated value of unexercised (vested and unvested) in-the-money options at the previous FYE, $P^{\prime}$ is the stock price in the month prior to the option grant date, and $P_{F Y E}$ is the stock price at the previous FYE. Note that this measure potentially over-estimates the true value. We winsorize this variable at the $10 \%$ level for regression analysis, which helps address this issue in extreme cases. For incentive-realignment purposes, we conjecture a positive relation between OOM and option backdating.

\footnotetext{
${ }^{8}$ Tracking the history of entire option portfolio to construct OOM measure is possible in some previous repricing studies because the sample size is usually relatively small. For instance, Carter and Lynch (2001) study 263 repricing firms in 1998. Chidambaran and Prabhala (2003) examine 213 repricing events between 1992 and 1997 while Brenner et al. (2000) analyze 133 repricings between 1992 and 1995.

${ }^{9}$ Chen (2004) follows Core and Guay (1999) and uses the average imputed moneyness of managers' stock option portfolios to study option repricing of 108 firms from 1994 to 1998.
} 


\subsubsection{The Agency Hypothesis}

In recent years there have been a number of cases where option repricing and backdating were linked to managerial self-dealing, which manifests itself in weak governance. For example, in 2006 William McGuire, the head of UnitedHealth Group, one of the largest US health insurers, was suspected of backdating options. An investigation by law firm Wilmer Cutler Pickering Hale found that: "Mr. McGuire was central to the options granting process and that the "full extent and nature" of financial relationships between him and the then-chairman of the company's compensation committee that had created a conflict of interest in 1999 "likely were not disclosed" to the board at the time". ${ }^{10}$

The empirical evidence on the relation between internal governance and option repricing is mixed. Chidambaran and Prabhala (2003) find that smaller boards, which are generally viewed as providing better governance, are more likely to reprice. Greater insider presence on the board (or its compensation committee) increases the likelihood of repricing (Brenner et al., 2000; Chance et al., 2000). However, Carter and Lynch (2001) find no relation between the board structure and option repricing. The evidence for option backdating is also mixed in the sense that Collins et al. (2009) find that option backdating results from weak governance, whereas Bizjak et al. (2009) do not find such a relation. A potential explanation for these different findings is that these studies measure governance differently: Collins et al. (2009) focus on variables regarding board independence while Bizjak et al. (2009) study board interlocks and consider board effectiveness.

In order to shed more light on the relation between governance and backdating, we test the Agency Hypothesis using a variety of governance variables that capture different aspects of corporate governance. These include variables on board independence as Collins

\footnotetext{
${ }^{10}$ See "Uncertainty hangs over UnitedHealth", Financial Times, October 16, 2006.
} 
et al. (2009), on board effectiveness as Bizjak et al. (2009), and on minority shareholder protection as Gao and Mahmudi (2011). Formally, our Agency Hypothesis is stated as follows:

H3: Firms backdate options for reasons of managerial self-dealing.

The following proxies measure board independence based on Collins et al. (2009). In all cases, a positive relation is hypothesized:

- Inside Director: percentage of inside directors on the board.

- Gray Director: percentage of gray outside directors on the board. An outside director is "gray" if (s)he is a former employee; is an employee of a significant service provider, supplier, or customer; is a recipient of charitable funds; is an interlocking director; or is a family member of an executive director.

- CEO Hire Director: percentage of outside directors who are appointed after the incumbent CEO took office.

- CEO Chair: a dummy variable that equals one if the CEO is also the chair of the board, and zero otherwise.

- Inside Director Compensation: a dummy variable that equals one if at least one inside director serves on the compensation committee, and zero otherwise.

In addition, similar to Bizjak et al. (2009), we use the following proxies:

- Board Size: as one additional board characteristic, board size is the number of directors on the board. Yermack (1996) finds that smaller boards are associated with higher firm value, suggesting that smaller boards are more effective.

- CEO Tenure: we use the difference between the first year of company involvement (based on records from Compustat, RiskMetrics, and other online sources) and the 
option grant year as a proxy for CEO tenure. CEOs with long tenure are more likely to be entrenched or to influence the board to pursue rent-seeking activities. So, longer CEO tenure can lead to weaker internal governance, although this relation is not supported by empirical evidence. For instance, Chidambaran and Prabhala (2003) show that CEO tenure is not statistically significantly different between repricers and control firms or between repricers and the universe of non-repricers.

- CEO Age: in order to be able to compare our results with previous studies we also use CEO age.

The following two proxies measure the degree of protection of minority shareholders:

- GIM Index: the Gompers, Ishii, and Metrick (2003) index, from now on the GIM index, is constructed using the incidence of 24 governance rules in relation to anti-takeover provisions that proxy for the level of shareholder rights. A firm with a higher GIM index is viewed as having inferior governance.

- Entrenchment Index: this index follows Bebchuk et al. (2009) is based on six anti-takeover provisions: staggered boards, limits to shareholder bylaw amendments, poison pills, golden parachutes, and supermajority requirements for mergers and charter amendments. Like the GIM index, a firm with a higher index is associated with a lower degree of minority shareholder protection and thus weak governance.

In short, if the managerial rent-seeking hypothesis (agency problems) holds, we expect the likelihood of option backdating to be higher for a firm with a high governance index, a large board with less board independence, and longer executive tenure (old age).

\subsubsection{Control variables}


In order to correct for influential factors found in previous studies, we include the following control variables in our analysis:

- Stock Volatility: stock volatility is the standard deviation of daily stock prices in the month of option grants. Stock volatility is a prerequisite for option backdating because higher volatility gives more leeway for choosing a favourable price to make adjustments. Without volatile stock price movements, the scope for option backdating is further reduced. High stock price volatility also indicates greater uncertainty for a typical risk-averse manager. Besides, as argued by Chen (2004), volatile stock price movements make option grants become more likely out-of-the-money. This gives rise to backdating for reincentivization. Therefore, consistent with Bizjak et al. (2009), we expect that stock price volatility is positively associated with option backdating.

- Dispensable Cash: we estimate dispensable cash by using cash minus interest expenses, scaled by total assets. One alternative for option backdating is to pay cash while leaving the existing options intact. Moreover, the liquidity constraint might lead to option backdating to implement certain compensation practices (Fang, 2010). As a result, we expect a negative relation between a firm's dispensable cash holdings and the likelihood of option backdating.

Other than the features described above, we expect that scheduled grants significantly reduce the likelihood of option backdating. Following Heron and Lie (2009), a grant is defined as scheduled if it occurs within one day of the one-year anniversary of a prior grant or is followed by a grant dated within one day of the one-year anniversary of the grant in question. Moreover, during the sample period, two major events occur that profoundly 
change the behaviour of firms and investors: the passage of the SOX in 2002 and the media attention to the issue of option backdating beginning in late 2005. Several recent studies show that the SOX has effectively deterred firms from engaging in option backdating after 2002 (e.g., Heron and Lie, 2007, 2009; Narayanan and Seyhun, 2008). However, Huang and $\mathrm{Lu}$ (2010) find that although the SOX mitigates option backdating, it is not until the media attention to scandals and the subsequent compensation disclosure rules implemented in 2006 that such opportunistic timing behaviour becomes obsolete. We use two dummy variables to capture the effects of the two events, and we expect that both decrease the likelihood of option backdating.

\section{Data and Methodology}

\subsection{Sample}

We obtain our sample of CEO stock option grants from the Thomson Financial Insider Filing database, which provides all insider transactions reported on SEC forms 3, 4, 5, and 144 in the U.S. We include transactions with the following derivative titles: OPTNS, EMPO, ISO, NONQ, CALL, WT, DIRO, RGHTS, and SAR. All of the sample transactions have a cleanse indicator of $\mathrm{R}$ ("data verified through the cleansing process"), H ("cleansed with a very high level of confidence"), or C ("a record added to nonderivative table or derivative table in order to correspond with a record on the opposing table"). We restrict our sample option grants to transactions that are granted or awarded to CEOs between 1999 and 2007. ${ }^{11}$ We require stock returns to be available from 20 trading days before to 20 trading days after the grant date. We further eliminate duplicate grants occurring on a given

\footnotetext{
${ }^{11}$ We include options granted until November 2007 because a month of subsequent stock returns is needed for estimation. We do not extend the sample period further to avoid the influences from the recent financial crisis.
} 
grant date so that there is only one grant for a given date and company combination, i.e., firm-grant-date observation.

This selection procedure leaves 26,092 firm-grant-date observations for 5,398 companies. Next, we match these transactions with available corporate governance data from the RiskMetrics Governance, accounting and executive compensation data from the Compustat, and stock price data from the Center for Research in Security Prices (CRSP). ${ }^{12}$ In the end our final sample consists of 6,830 CEO option grants across 1,303 S\&P1500 companies in the U.S. during the period of 1999 to 2007.

\subsection{Methodology for Estimating the Likelihood of Backdating Grants}

Intuitively, absent opportunistic timing of grants or of information flows around grants, stock returns before and after grant dates should display similar patterns. Specifically, the distribution of the difference between the returns for a given number of days before and after the grants should be centered around zero. Similar to Heron and Lie (2007, 2009), we use this reasoning to estimate the likelihood of grants' having been backdated. ${ }^{13}$

Following Lie (2005) and Heron and Lie (2007), for the sample CEO option grants, we adopt the event study approach and estimate the cumulative abnormal returns as the

\footnotetext{
12 The RiskMetrics Governance database publishes detailed listings of up to 30 corporate governance provisions for firms in corporate takeover defenses for more than 4,000 firms since 1990. The Compustat database provides annual and quarterly income statements, balance sheets, statements of cash flow, and supplemental data items on publicly held companies. Moreover, it provides summary compensation data in the Compustat ExecuComp. The CRSP database maintains a comprehensive collection of security price, return, and volume data for the NYSE, AMEX, and NASDAQ stock markets, among others.

${ }_{13}$ Estimated abnormal stock price movement around grant dates might result from various manipulative practices, such as option backdating (Heron and Lie, 2007), option springloading (Yermack, 1997), and option repricing (Callaghan et al., 2004). Heron and Lie (2007) nevertheless argue that the majority of abnormal returns around declared grant dates suggest option backdating. In addition, abnormal stock price patterns should vary depending on the purposes of these manipulative practices. More specifically, for option springloading, abnormal stock returns before grant dates should not be significantly different from zero. Other than that, the abnormal stock returns around the grant dates should have a "V" shape for option backdating.
} 
difference between the stock returns of the granting firm and the returns predicted by the Fama and French three-factor model. The estimation window lasts for 255 days, ending 46 days before the grant date. The event window comprises 41 days in total, starting from 20 trading days before and ending 20 trading days after the event. We choose the interval of 20 trading days because previous studies (e.g., Heron and Lie, 2009) suggest that most of the abnormal returns around grants occur during the month immediately before and after the grants. We use the abnormal return difference before and after the grants as our estimate of the likelihood of option backdating. ${ }^{14}$

We classify option grants as backdated when their abnormal return differences, i.e., $\mathrm{AR}(+1,+20)-\mathrm{AR}(-20,-2)$, rank in the highest decile of the whole sample distribution, given that their $\operatorname{AR}(-20,-2)$ values are negative and $A R(+1,+20)$ values are positive. In our sample, the lower bound of the highest decile is $17.16 \% .^{15}$ Heron and Lie (2009) estimate that, on average, $18.9 \%$ of all top executive option grants are manipulated, with $23 \%$ before and $10 \%$ after the 2002 SOX takes effect. At the firm level, $34.15 \%$ of our sample firms are estimated to have their CEO stock option grants backdated at some point during the period from 1999 to $2007,{ }^{16}$ compared with $29.2 \%$ between 1996 and 2005, as reported by Heron and Lie (2009). Alternatively, of the 5,451 firm years in our sample, approximately $10.29 \%$ are classified as backdaters, compared to $14 \%$ in Bizjak et al. (2009) and $12.3 \%$ in Collins et al. (2009). Therefore, our choice of the top $10 \%$ as a threshold provides a conservative

\footnotetext{
${ }^{14}$ In our sample, the correlation between the difference in abnormal returns (the likelihood of backdating) and that in normal returns (the profitability of backdating)) is 0.7386 . We run separate tests with the dummy variable based on the difference in normal returns as the proxy for backdating. The results are similar.

${ }^{15}$ It is $24.78 \%(43.86 \%)$ when using the top $5 \%(1 \%)$ threshold.

${ }^{16}$ When applying the top $5 \%$ threshold as an alternative proxy for option backdating, the percentage of manipulated firms drops to $18.96 \%$, which provides a more conservative estimate.
} 
estimate of option backdating while reducing potential noise in the data. ${ }^{17}$

Note that as of September $4^{\text {th }}, 2007$, the Wall Street Journal reported 141 companies associated with past option backdating practices. Among these companies, 96 companies were subject to some punitive actions for various reasons by the SEC or the Justice Department. Among these companies, 57 are in our sample in which 26 companies are identified to have backdated options during the sample period. So, we believe that our method of estimating backdaters is valid, in spite of being conservative, and that our backdating sample does capture a significant proportion of true backdaters.

\section{Empirical Results}

\subsection{Determinants of Option Backdating}

\subsubsection{Summary Statistics}

Table 1 shows the descriptive statistics.

[Please Insert Table 1 here]

In Panel A, the market value of slightly more than half of the firms is less than 2 billion U.S. dollars. In terms of industrial classification, as shown in Panel B, the computers and electronic parts industry has the most options that are potentially being backdated $(20.35 \%),{ }^{18}$ followed by the manufacturing industry $(21.23 \%)$ and the services industry

\footnotetext{
${ }^{17}$ Heron and Lie (2009) estimate the likelihood by using the absolute return difference and a dummy indicating whether this difference is positive. Collins el al. (2009) classify a grant as backdated if the stock price at the grant date ranks in the lowest decile of the firm's stock price distribution over a 240-day window around the option grant date. Bizjak et al. (2009) first sort firms based on the stock volatility and then identify grants as being backdated by the magnitude of the post- to pre-grant return difference that corresponds to a pre-specified confidence level (e.g., $95 \%$ or $99 \%$ ).

${ }^{18}$ The percentage increases to $33.16 \%$ when using a broader definition of the high-technology industry (computers \& electronic parts and software \& technology, and biotech industry), as in Chidambaran and Prabhala (2003).
} 
(8.77\%). In terms of the timing of the option grants, Panel C shows that, until 2006, the issuance of option grants increases steadily over time. Moreover, consistent with previous studies, the estimated number of backdated options is higher in general before 2005 . Particularly, between 1999 and 2002, approximately 12\%-17\% of option grants are estimated to have been backdated, similar to the findings in Heron and Lie (2009).

Panel D displays the grant type distribution according to two categories, i.e., in-the-money, at-the-money, and out-of-the-money versus scheduled and unscheduled option grants, across three groups (whole sample, non-backdated, and backdated grants). In general, the grant type distribution of non-backdated options is similar to that of total options. In other words, our backdating sample is different from the non-backdating sample and the whole sample as well. We also find that unscheduled and out-of-the-money options are more subject to backdating.

\subsubsection{Univariate Comparisons}

Table 2 shows between-sample (non-backdated grants vs. backdated grants) comparisons of selected firm- and CEO-specific attributes, as well as internal governance.

[Please Insert Table 2 here]

Overall, most of the variables show discrepancies between non-backdated and backdated option grants at the 5\% level of statistical significance for both mean and Wilcoxon rank-sum tests. A firm with a higher propensity for backdating its CEO's option grants is typically smaller and younger. These results for Firm Size and Firm Age are in line with $H 1$, the Retention Hypothesis. In line with the same hypothesis, backdating firms also have higher Growth Opportunity and a lower Profitability. The result on Share Ownership 
goes against this hypothesis: we expected managers of backdating firms to have lower Share Ownership, but they have significantly higher Share Ownership instead.

Consistent with $\mathrm{H} 2$, the Incentive Hypothesis, we find that backdated options are offered to executives with higher Option Holdings. Generally speaking, the means and medians of Out-of-Moneyness (OOM) are similar in backdated and non-backdate options, a result that seemingly goes against this hypothesis. Yet, the Wilcoxon rank-sum test result shows that there is a statistically significant difference between the underlying distributions of these two groups of options (P-value $=0)$. Specifically, backdated options have higher rank than non-backdated options. This provides evidence that backdated options are granted to CEOs whose option portfolios are associated with a higher degree of OOM.

The first part of the Agency Hypothesis tests whether directors use their influence to backdate options. We find that for almost all variables there is no significant difference between backdating and non-backdating firms. The notable exception is the Inside Director variable that measures the percentage of inside directors on the board. In line with our expectations, we find that backdating firms have more inside directors than non-backdating firms. This result also confirms the univariate result of Collins et al. (2009), who also finds that backdating firms have a significantly higher percentage of inside directors than non-backdating firms. The finding that backdating firms have a smaller Board Size goes against this hypothesis, since smaller boards are expected to be more efficient. This result is in line with Bizjak et al. (2009). CEO Tenure is significantly shorter and CEO Age is significantly lower for backdaters, both providing evidence against $H 3$. The result on $C E O$ Age is in line with Bizjak et al. (2009). 
The second part of the Agency Hypothesis tests whether backdating firms are more likely to expropriate minority shareholders than non-backdating firms. The surprising result is that the opposite seems to be the case: both the GIM Index and the Entrenchment Index are lower for backdating firms compared to non-backdating firms. This finding goes against our H3, but consistent with Gao and Mahmudi (2011). Finally, our results on control variables show that backdating firms have higher Stock Volatility, consistent with Bizjak et al. (2009), and a higher Dispensable Cash Ratio, which is contrary to our conjecture.

\subsubsection{Multivariate Analysis}

In this section, we use the following probit model to examine the relations between explanatory variables and the propensity for option backdating,

$\left.\operatorname{Prob}_{\left(\text {Backdate }_{i t}\right.}\right)=\alpha_{0}+\beta_{1} *$ Firm Size $_{i t-1}+\beta_{2} *$ Firm Age $_{i t}+\beta_{3} *$ Growth Opportunity $_{i t-1}$ $+\beta_{4} *$ Profitability $_{i t-1}+\beta_{5} *$ Share Ownership ${ }_{i t}+\beta_{6} *$ Option Holdings $_{i t}+\beta_{7} *$ Out-of-Moneyness Hit $_{\text {-M }}$ $+\beta_{8} *$ Governance proxies $i t+\beta_{9} *$ Stock $_{\text {Volatility }}+\beta_{10} *$ Dispensable $_{\text {Cash }}$ it- $_{1}+\beta_{11} *$ Scheduled $_{i t}$ $+\varepsilon_{i t}$

The dependent variable Backdate is a dummy variable equal to 1 for firm-grant-date observations whose abnormal stock return differences rank above the top $10 \%$ of the entire sample, under the condition that $\operatorname{AR}(-20,-2)$ is negative and $\operatorname{AR}(+1,+20)$ is positive, and zero otherwise. Table 3 shows the estimated coefficients (marginal effects and standardized coefficients alike) from seven probit models that link option backdating propensity to a number of explanatory variables, testing for the retention, incentive, and agency hypotheses described in Section 2.2. Standard deviations are clustered at the 2-digit SIC level in all model specifications. 
[Please Insert Table 3 here]

To test the three motives for backdating, Models 1 to 5 include the same set of explanatory variables for the retention and incentive hypothesis but use different measures for internal governance. The coefficients for Growth Opportunity and Share Ownership are positive, but are not significant in any of the five models. Nevertheless, the significantly negative coefficients for Firm size, Firm Age, and Profitability in all five models give a clear support for $H 1$, the retention hypothesis in the sense that smaller and younger firms tend to backdate their CEO option grant dates more. Additionally, when a firm encounters a decline in accounting performance in the previous year, the likelihood of options' being backdated is higher. Finally in line with the retention hypothesis, we find that firms in the technology industry have a higher backdating propensity.

The coefficient for Option Holdings is positive and is significant in three of these five models. The coefficient for Out-of-Moneyness is also positive and is significant at the $1 \%$ level in all five models. These results mean that option holdings have a positive relation with option backdating and that options tend to be backdated when a CEO's option portfolio becomes more out-of-the-money. Both results provide evidence for the incentive hypothesis $(H 2)$.

We find little support for the hypothesis that stock option backdating is associated with less board independence. Only one of the governance variables in Model 1 is significant, i.e., a significantly negative relation exists between backdating and CEO Tenure. This result confirms the univariate analysis but goes against H3. In Model 2 we find a significantly negative relation at the $1 \%$ level between backdating and Board Size. This result also goes against $H 3$, because small boards are expected to be more effective. In 
Models 3 and 4 respectively, we find significantly negative relations between option backdating and the GIM Index and the Entrenchment Index. These results are contrary to H3. In Model 5, we follow Model 2 and replace CEO Tenure by CEO Age, ${ }^{19}$ whose coefficient is negative but not statistically significant.

In Model 6, as one supplemental test, we use different control variables in combination with the governance variables, comparable with Collins et al. (2009). In that model, we find a positive relation between the number of Inside Directors and backdating. This result provides the only minor evidence in favour of $H 3$. Finally, we find that options granted since the 2002 SOX are less likely to be backdated and that higher stock volatility is associated with more backdating.

These results still hold after controlling for industry and year fixed effects, as shown in Model 7. ${ }^{20}$ The marginal-effects estimates suggest that a drop of 10 million dollars in firm size increases the backdating likelihood by $2.8 \%$. When a firm is one year younger, its propensity to backdate increases by $0.1 \%$. A $100 \%$ decline in profitability increases such likelihood by $8.9 \%$. Despite somewhat lower statistical significance (at $5 \%$ level), in terms of economic significance Profitability plays the most prominent role in the decision to backdate. On the other hand, when the Out-of-Moneyness of the CEO option portfolio increases by $\$ 1$, the backdating likelihood increases by $1.8 \%$. When there is one fewer director on the board, the likelihood of backdating goes up by $0.2 \%$. Note that this likelihood increases by $1.3 \%$ when the standard deviation of stock price during the grant month increases by $100 \%$.

\footnotetext{
${ }^{19}$ The correlation between these two variables is 0.3438 (statistically significant at the $1 \%$ level).

${ }^{20}$ We use Board Size as the proxy for governance because it gives highest explanatory power $(9.47 \%$ in Model 2) compared with models using alternative proxies. The explanatory power increases to $11.57 \%$ in Model 7.
} 
Moreover, the standardized coefficients in Table 3 indicate that, robust to all model specifications, the main driver is firm size (the retention hypothesis), followed by OOM (the incentive hypothesis), stock volatility, and firm age (the retention hypothesis). In sum, results suggest that option backdating is more for retention considerations and, to a lesser extent, for reincentivization. This result is consistent with the option repricing literature. Most of our results show that option backdating is not related to weaker governance or managerial entrenchment. Indeed, for the GIM Index and the Entrenchment Index results indicate that backdating is associated with superior governance and less entrenchment. This finding is in contrast with the typical managerial power view.

\subsection{Option Backdating and Subsequent Performance}

After exploring the determinants of backdating, naturally the next question that we ask is concerning its consequences. Other than the legal ramifications, we are more interested in one real consequence: whether backdating is detrimental to firm value ex post, as the agency hypothesis indicates. To that end, we investigate the relation, if any, between option backdating and subsequent firm performance, in terms of both accounting and market measures. This can help us to further test the incentive hypothesis by examining the effectiveness of reincentivization.

\subsubsection{Accounting Performance}

The analysis in Section 4.1.3 shows that the decision to reset option grant dates is very likely not random. This is an example of sample selection. As such, rather than the simple linear models commonly adopted in the option backdating literature, treatment effect 
models are more appropriate than conventional Heckman sample selection models. ${ }^{21} \mathrm{We}$ view the decision to backdate option grants, a binary variable, as a treatment to re-incentivize managers, as the incentive hypothesis suggests. Ideally we should examine whether performance is better than it would have been in the absence of such behaviour. ${ }^{22}$ Since the latter cannot be observed, we use the performance of non-backdating firms (the untreated) as a proxy (i.e., assuming that the outcomes of the untreated are independent of treatment after controlling for a set of independent variables) and in the meantime control for firms' choices to backdate. ${ }^{23}$

In this section, we use forward return on assets as a proxy for post-backdating operating performance to incorporate subsequent firm performance into our previous multivariate analysis. More specifically, we use the treatment-effects model (Greene, 2012) that estimates the effect of an endogenous binary treatment, Backdate ${ }_{i t}$, on a continuous, fully observed variable Profitability it+1 $_{\text {, }}$, conditional on two sets of explanatory variables for each dependent variable. Formally, the primary interest is the following model specification:

Profitability $_{i t+1}=\alpha_{0}+\beta_{1} *$ Firm Size $e_{i t}+\beta_{2} *$ Profitability $_{i t}+\beta_{3} *$ Backdate $_{i t}+\varepsilon_{i t}$

where Backdate $_{i t}$ is an endogenous dummy variable indicating whether the treatment is assigned or not. The binary decision to obtain the treatment Backdate ${ }_{i t}$ is modelled as the outcome of an unobserved latent variable, Backdate ${ }_{i t}$, which is assumed to be a linear

\footnotetext{
${ }^{21}$ In a treatment effect model, (1) a dummy variable indicating the treatment condition is directly entered into the regression equation and (2) the outcome of the regression equation is always observed regardless of the treatment condition (Fraser and Guo, 2009).

${ }^{22}$ Here we choose to estimate the Average Treatment Effect on the Treated (ATET) instead of the Average Treatment Effect (ATE) that requires a stronger conditional independence assumption. This assumption refers to the condition that the outcomes are independent of treatment, conditional on a set of explanatory variables.

${ }^{23}$ This gives us a consistent estimate of the ATET mentioned in footnote 22. See Greene (2012) for detailed discussion.
} 
function of the exogenous covariates and a random component. In our study, the binary Backdate $^{*}$ it variable is a function of a set of selection variables shown in Section 4.1.3.

The decision to obtain the treatment, i.e., to have existing option grants backdated, is a binary variable and made according to the rule,

$$
\text { Backdate }_{i t}=\left\{\begin{array}{c}
1, \text { if } \text { Backdate }_{i t}^{*}>0 \\
0, \text { otherwise }
\end{array}\right.
$$

where Backdate ${ }_{i t}=f\left(\right.$ Firm Size $_{i t-1}$, Firm Age $_{i t}$, Growth Opportunity $_{i t-1}$, Profitability $_{i t-1}$,

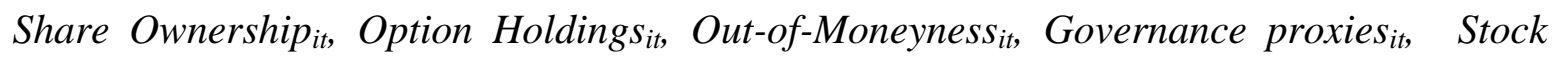
Volatility $_{i t}$, Dispensable Cash ${ }_{i t-1}$, Scheduled $\left._{i t}\right)$.

Table 4 reports maximum likelihood estimates.

[Please Insert Table 4 here]

Similar to the model specifications in the previous multivariate tests, Models 1 to 5 are identical except for adopting different proxies for internal governance. On average, after controlling for contemporaneous Firm Size and Profitability (together with industry and year fixed effects), the act of backdating CEO option grants is not related to subsequent operating performance. Compared to Table 3, we find that the same set of determinants of backdating seems able to explain backdating when using the treatment-effects model. Moreover, Growth Opportunity and Option Holdings become statistically significant. It thus suggests that, when taking into account subsequent firm performance and viewing option backdating as a treatment instead of a random or dummy variable, fast growing firms and CEOs holding more option grants also increase the likelihood of backdating. ${ }^{24}$

\footnotetext{
${ }^{24}$ The results are qualitatively the same when we employ the two-stage least squares estimation (results not tabulated and available upon request).
} 
These results give further evidence that the rationale behind backdating is more for retention and less for incentive realignment, resembling the mechanism of option repricing. Again, we do not find evidence of inferior corporate governance and/or higher management entrenchment in the selection process.

\subsubsection{Market Performance}

Other than short-term performance, it is also important to investigate whether option backdating has any consequences for a firm's long-term performance. In this section, we employ the calendar-time Fama-French four-factor model to estimate abnormal returns. We follow standard procedures in the literature with two approaches. For the grant-based approach, each month we form portfolios consisting of all option grants that are issued within the last $n$ years (where $n$ is the length of the holding period). ${ }^{25}$ For the firm-based approach, the monthly portfolios contain all firms that issue an option grant within the last $n$ years. $^{26}$ The portfolios are rebalanced monthly, with those that reach the end of the holding period dropping out and new ones coming in. If a firm is delisted before the end of the holding period, we include its delisting return in computing the portfolio return. Then, we calculate the portfolio $i$ mean monthly abnormal return $\left(\alpha_{i}\right)$ by regressing its excess return on the four Fama-French factors:

$$
R_{i t}-R_{t}^{f}=\alpha_{i}+\beta_{i} *\left(R_{t}^{\operatorname{mar}}-R_{t}^{f}\right)+\gamma_{i} * S M B_{t}+\delta_{i} * H M L_{t}+\lambda_{i} * W M L_{t}+\varepsilon_{i t}
$$

where $R_{i}$ is the equal-weighted portfolio $i$ return, $R^{f}$ is the risk-free rate (one month

\footnotetext{
${ }^{25}$ This n-year window represents ( $\left.n^{*} 12\right)-1$ months. Unlike $n * 12$ months commonly used in the literature, we do not include the first month after the event to avoid overestimation for the sample group due to its higher return in the post-grant period.

${ }^{26}$ Similar to Collins et al. (2009), the backdating firm-months consist of firm-months that have at least one backdated CEO stock option grant. The non-backdating firm-months consist of firm-months that have all non-backdated CEO stock option awards.
} 
Treasury bill rate), $R^{\text {mar }}$ is the CRSP value-weighted market portfolio return, $S M B$ is the return of a portfolio of small stocks minus the return of a portfolio of large stocks, $H M L$ is the return of a portfolio of high book-to-market stocks minus the return of a portfolio of low book-to-market stocks, and WML is the return of a portfolio of high momentum stocks (winner) minus the return of a portfolio of low momentum stocks (loser). We exclude portfolios consisting of less than 4 companies and the corresponding portfolios of their pairs, if anything.

Table 5 shows the (mean) abnormal returns for both types of portfolios consisting of backdated and non-backdated options in terms of the grant- and the firm-based approaches.

[Please Insert Table 5 here]

Overall, the mean abnormal return for the backdated option portfolio is positive and statistically significant at the $10 \%$ level only in the 2-year horizon. Nevertheless, when compared with the non-backdated option portfolio, the abnormal return difference is never statistically significant. As a result, option backdating seems unable to provide incentives that lead to outperformance in the long run (no evidence for underperformance either). To summarize, the findings in Section 4.2. suggest that option backdating in general does not serve the incentive-realignment purposes, regardless of the time horizon. Therefore, option backdating is arguably to retain valuable employees more than to reincentivize them, which is consistent with option repricing. ${ }^{27}$

\footnotetext{
27 We conduct a series of robustness checks using alternative methods of classification and/or sample constructions, i.e., filed-late (and unscheduled) options granted in the post-SOX period following Heron and Lie (2007); the top $10 \%$ threshold for at-the-money and unscheduled grants similar to Heron and Lie (2007, 2009); the bottom $10 \%$ threshold over a 240-day window for unscheduled grants similar to Collins et al. (2009). As a whole, consistent with the main results, we do not find relations between backdating and subsequent firm performance. Similarly, different hypotheses show varying degrees of strength in each alternative model
} 


\section{Concluding Remarks}

The practice of employee option backdating is not without controversy. For example, the widely used textbook of Hull (2012) on derivative securities argues (page 341): "No discussion of employee stock options would be complete without mentioning backdating scandals." In this paper we study the motives for employee stock option backdating. Our somewhat surprising overall finding is that agency problems hardly seem to play a role in the motives for CEO option backdating. We find very limited evidence for managerial self-dealing. There is some evidence that backdating firms have more inside directors on the board. However, even the evidence for that result is not completely conclusive. In fact, we find evidence contrary to the agency hypothesis, i.e., backdating firms have better protection of minority shareholders than firms that do not backdate. Our study provides an interesting link between the findings of Collins et al. (2009) and Bizjak et al. (2009).

Motives that do find more support in our analysis are employee retention and incentivisation of employees. In general, our results show that the main driver of option backdating is firm size, followed by executive option portfolios being out-of-the-money, stock volatility, and firm age. To our best knowledge, this paper is the first study that considers option out-of-moneyness in this line of literature. In sum, our findings indicate that option backdating is seemingly beyond agency problems. Given the sticky governance structure, the systemic use of option backdating across companies and the intermittent pattern within a company documented by Heron and Lie (2009) cannot be merely explained by (inferior) governance.

specification, with limited evidence supporting the agency hypothesis. These supplemental test results are not tabulated and available upon request. 


\section{References}

Aboody, D. and R. Kasznik (2000), 'CEO Stock Option Awards and the Timing of Corporate Voluntary Disclosures', Journal of Accounting Economics, Vol. 29, No. 1, pp. 73-100.

Acharya, V., K. John and R. Sundaram (2000), 'On the Optimality of Resetting Executive Stock Options', Journal of Financial Economics, Vol. 57, No. 1, pp. 65-101.

Armstrong, S. and D. Larcker (2009), 'Discussion of "The Impact of the Options Backdating Scandal on Shareholders and Taxes and the Backdating of Stock Option Exercise Dates"', Journal of Accounting and Economics, Vol. 47, No. 1\&2, pp. 50-58.

Bebchuk, L., A. Cohen and A. Ferrell (2009), 'What Matters in Corporate Governance?', Review of Financial Studies, Vol. 22, No. 2, pp. 783-827.

Bernile, G. and G. Jarrell (2009), 'The Impact of the Options Backdating Scandal on Shareholders', Journal of Accounting and Economics, Vol. 47, No. 1\&2, pp. 2-26.

Bizjak, J., M. Lemmon and R. Whitby (2009), 'Option Backdating and Board Interlocks', Review of Financial Studies, Vol. 22, No. 11, pp. 4821-47.

Brenner, M., R. Sundaram and D. Yermack (2000), 'Altering the Terms of Executive Stock Options', Journal of Financial Economics, Vol. 57, No. 1, pp. 103-28.

Brockman, P., X. Martin and E. Unlu (2010), 'Executive Compensation and the Maturity Structure of Corporate Debt', Journal of Finance, Vol. 65, No. 3, pp. 1123-1161.

Callaghan, S., P. Saly and C. Subramanian (2004), 'The Timing of Option Repricing', Journal of Finance, Vol. 59, No. 4, pp. 1651-76.

Carter, M. and L. Lynch (2001), 'An Examination of Executive Stock Option Repricing', Journal of Financial Economics, Vol. 61, No. 2, pp. 207-25.

(2003), 'The Consequences of the FASB's 1998 Proposal on Accounting for Stock Option Repricing', Journal of Accounting and Economics, Vol. 35, No. 1, pp. 51-72.

Chance, D., R. Kumar and R. Todd (2000), 'The "Repricing" of Executive Stock Options', Journal of Financial Economics, Vol. 57, No. 1, pp. 129-54.

Chauvin, K. and C. Shenoy (2001), 'Stock Price Decreases Prior to Executive Stock Option Grants', Journal of Corporate Finance, Vol. 7, No. 1, pp. 53-76.

Chen, M. (2004), 'Executive Option Repricing, Incentives, and Retention', Journal of Finance, Vol. 59, No. 3, pp. 1167-200.

Chidambaran, N. and N. Prabhala (2003), 'Executive Stock Option Repricing, Internal Governance Mechanisms, and Management Turnover', Journal of Financial Economics, Vol. 69, No. 1, pp. 153-89.

Collins, D., G. Gong and H. Li (2009), 'Corporate Governance and Backdating of Executive Stock Options', Contemporary Accounting Research, Vol. 26, No. 2, pp. 403-45. 
Core, J. and W. Guay (1999), 'The Use of Equity Grants to Manage Optimal Equity Incentive Levels', Journal of Accounting and Economics, Vol. 28, No. 2, pp. 151-184.

----- ----- (2002), 'Estimating the Value of Employee Stock Option Portfolios and Their Sensitivities to Price and Volatility', Journal of Accounting Research, Vol. 40, No. 3, pp. 613-630.

Dhaliwal, D., M. Erickson and S. Heitzman (2009), 'Taxes and the Backdating of Stock Option Exercise Dates', Journal of Accounting and Economics, Vol. 47, No. 1\&2, pp. 27-49.

Fang, H. (2010), 'The Economic Rationale for Option Backdating: Incentive-based Explanations', Doctoral Thesis.

Fraser, M. and S. Guo (2009), 'Propensity Score Analysis: Statistical Methods and Applications', $1^{\text {st }}$ ed. Sage Publications Inc.

Gao, H. and H. Mahmudi (2011), 'Backdating Executive Stock Option Grants: Is It All Agency?', Working Paper.

Gompers, P., J. Ishii and A. Metrick (2003), 'Corporate Governance and Equity Prices', Quarterly Journal of Economics, Vol. 118, No. 1, pp. 107-55.

Greene, W. (2012), 'Econometric Analysis', 7th ed. Upper Saddle River, NJ: Prentice Hall.

Heron, R. and E. Lie (2007), 'Does Backdating Explain the Stock Price Pattern Around Executive Stock Option Grants?', Journal of Financial Economics, Vol. 83, No. 2, pp. 271-95.

(2009), 'What Fraction of Stock Option Grants to Top Executives Have Been Backdated or Manipulated?', Management Science, Vol. 55, No. 4, pp. 513-25.

Huang, W. and H. Lu (2010), 'Timing of CEO Stock Option Grants and Corporate Disclosures: New Evidence from the Post-SOX and Post-backdating-scandal Era', Working Paper.

Hull, J. (2012), 'Options, Futures, and Other Derivatives', 8th ed. Harlow (UK) Pearson Education Limited.

Jensen, C. and H. Meckling (1976), 'Theory of the Firm: Managerial Behavior, Agency Costs, and Ownership Structure', Journal of Financial Economics, Vol. 3, No. 4, pp. 305-60.

Lie, E. (2005), 'On the Timing of CEO Stock Option Awards', Management Science, Vol. 51, No. 5, pp. 802-12.

Mehran, H. and D., Yermack (1997), 'Compensation and Top Management Turnover', Working Paper (New York University).

Morck, R., A. Shleifer and R. Vishny (1988), 'Management Ownership and Market Valuation: An Empirical Analysis', Journal of Financial Economics, Vol. 20, No. 1\&2, pp. 293-315.

Narayanan, M., C. Schipani and H. Seyhun (2007), 'The Economic Impact of Backdating of Executive Stock Options', Michigan Law Review, Vol. 105, pp. 1597-642. 
Narayanan, M. and H. Seyhun (2008), 'The Dating Game: Do Managers Designate Option Grant Dates to Increase Their Compensation?', Review of Financial Studies, Vol. 21, No. 5, pp. 1907-45.

Sauer, M. and Z. Sautner (2008), 'Stock Option Repricing in Europe', Working Paper (University of Amsterdam).

Scholes, M. (1991), 'Stock and Compensation', Journal of Finance, Vol. 46, No. 3, pp. 803-23.

Veld, C. (2003), 'Analysis of a practical formula for the valuation of employee stock options', Applied Economics Letters, Vol. 10, No. 4, pp. 205-208.

Wall Street Journal Online, 2007, Options Scorecard, The September version.

Yermack, D. (1996), 'Higher Market Valuation of Companies with Small Boards of Directors', Journal of Financial Economics, Vol. 40, No. 2, pp. 185-211.

----- (1997), 'Good Timing: CEO Stock Option Awards and Company News Announcements', Journal of Finance, Vol. 52, No. 2, pp. 449-76. 


\section{Table 1 \\ Sample Statistics}

This table provides summary statistics of sample firms/grants. Panel A displays the firm size distribution, in which the size is proxied by the (mean) market value of sample firms between 1999 and 2007. Panels B displays, grantwise, their industrial orientations, in which the industrial classification is based on SIC codes using the classification by Chidambaran and Prabhala (2003). A grant is assumed to be backdated when its value of AR(+1,+20)-AR(-20,-2) is ranked among the top $10 \%$ of all sample grants, under the condition that its $\operatorname{AR}(-20,-2)$ is negative and $\mathrm{AR}(+1,+20)$ is positive. Panel C reports the grant year distribution. Panel D shows the grant type distribution. A grant is defined as scheduled if it occurs within one day of the one-year anniversary of a prior grant or is followed by a grant dated within one day of the one-year anniversary of the grant in question. A grant is at-the-money (out-ofthe-money/in-the-money) if its exercise price is equal to (larger/lower than) the close price on the grant date.

\begin{tabular}{lrr}
\hline \multicolumn{3}{c}{ Panel A: Size (firm-wise) } \\
\hline $\begin{array}{l}\text { Market Value } \\
\text { (US\$ million) }\end{array}$ & Number of Firms & Fraction (\%) \\
\hline$<500$ & 189 & 14.50 \\
$500-1,000$ & 222 & 17.04 \\
$1,000-2,000$ & 267 & 20.49 \\
$2,000-3,000$ & 116 & 8.90 \\
$3,000-4,000$ & 91 & 6.98 \\
$4,000-5,000$ & 52 & 3.99 \\
$5,000-6,000$ & 51 & 3.91 \\
$6,000-7,000$ & 28 & 2.15 \\
$7,000-8,000$ & 25 & 1.92 \\
$8,000-9,000$ & 28 & 2.15 \\
$9,000-10,000$ & 19 & 1.46 \\
$>10,000$ & 215 & 16.50 \\
Sample Size & 1,303 & 100.00 \\
\hline
\end{tabular}

\begin{tabular}{lrrrrr}
\hline \multicolumn{4}{c}{ Panel B: Industry (grant-wise) } & & \\
\hline \multicolumn{1}{c}{ Industry } & $\begin{array}{c}\text { Number of } \\
\text { Total Grants }\end{array}$ & $\begin{array}{c}\text { Number of } \\
\text { Non-Backdated } \\
\text { Options }\end{array}$ & Fraction (\%) & $\begin{array}{c}\text { Number of } \\
\text { Backdated } \\
\text { Options }\end{array}$ & Fraction (\%) \\
\hline Agriculture \& Food & 191 & 183 & 2.93 & 8 & 1.40 \\
Mining & 48 & 44 & 0.70 & 4 & 0.70 \\
Construction & 83 & 72 & 1.15 & 11 & 1.93 \\
Oil \& Petroleum & 252 & 236 & 3.78 & 16 & 2.81 \\
Small Scale Manufacturing & 327 & 302 & 4.83 & 25 & 4.39 \\
Chemicals/related manufacturing & 893 & 822 & 13.16 & 71 & 12.46 \\
Industrial Manufacturing & 619 & 569 & 9.11 & 50 & 8.77 \\
Computers \& Electronic Parts & 810 & 694 & 11.11 & 116 & 20.35 \\
Printing \& Publishing & 147 & 143 & 2.29 & 4 & 0.70 \\
Transportation & 221 & 197 & 3.15 & 24 & 4.21 \\
Telecommunication & 102 & 94 & 1.50 & 8 & 1.40 \\
Utilities & 354 & 337 & 5.39 & 17 & 2.98 \\
Wholesale & 210 & 191 & 3.06 & 19 & 3.33 \\
Retail & 401 & 368 & 5.89 & 33 & 5.79 \\
Services & 571 & 521 & 8.34 & 50 & 8.77 \\
Financials & 884 & 843 & 13.49 & 41 & 7.19 \\
Software \& Technology & 422 & 371 & 5.94 & 51 & 8.95 \\
Biotech & 283 & 261 & 4.18 & 22 & 3.86 \\
Sample Size & 6,818 & 6,248 & 100.00 & 570 & 100.00 \\
\hline
\end{tabular}




\begin{tabular}{lrrrrr}
\hline \multicolumn{5}{c}{ Panel C: Year (grant-wise) } \\
\hline Year & $\begin{array}{c}\text { Number of } \\
\text { Total Grants }\end{array}$ & $\begin{array}{c}\text { Number of } \\
\text { Non-Backdated } \\
\text { Options }\end{array}$ & Fraction (\%) & $\begin{array}{c}\text { Number of } \\
\text { Backdated } \\
\text { Options }\end{array}$ & Fraction (\%) \\
\hline 1999 & 500 & 441 & 7.05 & 59 & 10.30 \\
2000 & 550 & 470 & 7.51 & 80 & 13.96 \\
2001 & 687 & 579 & 9.25 & 108 & 18.85 \\
2002 & 727 & 640 & 10.23 & 87 & 15.18 \\
2003 & 908 & 839 & 13.41 & 69 & 12.04 \\
2004 & 917 & 857 & 13.70 & 60 & 10.47 \\
2005 & 949 & 911 & 14.56 & 38 & 6.63 \\
2006 & 836 & 795 & 12.71 & 41 & 7.16 \\
2007 & 756 & 725 & 11.59 & 31 & 5.41 \\
Sample Size & 6,830 & 6,257 & 100.00 & 573 & 100.00 \\
\hline
\end{tabular}

\begin{tabular}{|c|c|c|c|c|c|c|c|c|c|c|c|c|c|}
\hline \multicolumn{14}{|c|}{ Panel D: Grant Type } \\
\hline & & \multicolumn{4}{|c|}{ Total Option Grants } & \multicolumn{4}{|c|}{ Non-Backdated Options } & \multicolumn{4}{|c|}{ Backdated Options } \\
\hline & & $\begin{array}{l}\text { In-the- } \\
\text { money }\end{array}$ & $\begin{array}{l}\text { At-the- } \\
\text { money }\end{array}$ & $\begin{array}{c}\begin{array}{c}\text { Out-of- } \\
\text { the- } \\
\text { money }\end{array} \\
\end{array}$ & $\begin{array}{l}\text { Sub- } \\
\text { total }\end{array}$ & $\begin{array}{l}\text { In-the- } \\
\text { money }\end{array}$ & $\begin{array}{l}\text { At-the- } \\
\text { money }\end{array}$ & $\begin{array}{c}\begin{array}{c}\text { Out-of- } \\
\text { the- } \\
\text { money }\end{array} \\
\end{array}$ & $\begin{array}{l}\text { Sub- } \\
\text { total }\end{array}$ & $\begin{array}{l}\text { In-the- } \\
\text { money }\end{array}$ & $\begin{array}{l}\text { At-the- } \\
\text { money }\end{array}$ & $\begin{array}{l}\text { Out-of- } \\
\text { the- } \\
\text { money }\end{array}$ & $\begin{array}{l}\text { Sub- } \\
\text { total }\end{array}$ \\
\hline \multirow[t]{2}{*}{ Unscheduled } & Number & 1,270 & 2,077 & 1,055 & 4,402 & 1,153 & 1,881 & 953 & 3,987 & 117 & 196 & 102 & 415 \\
\hline & Fraction (\%) & 18.60 & 30.41 & 15.45 & 64.46 & 18.43 & 30.07 & 15.23 & 63.73 & 20.42 & 34.21 & 17.80 & 72.43 \\
\hline \multirow[t]{2}{*}{ Scheduled } & Number & 733 & 1,035 & 659 & 2,427 & 690 & 971 & 608 & 2,269 & 43 & 64 & 51 & 158 \\
\hline & Fraction (\%) & 10.73 & 15.16 & 9.65 & 35.54 & 11.03 & 15.52 & 9.72 & 36.27 & 7.50 & 11.17 & 8.90 & 27.57 \\
\hline \multirow[t]{2}{*}{ Sub-total } & Number & 2,003 & 3,112 & 1,714 & 6,829 & 1,843 & 2,852 & 1,561 & 6,256 & 160 & 260 & 153 & 573 \\
\hline & Fraction (\%) & 29.33 & 45.57 & 25.10 & 100.00 & 29.46 & 45.59 & 24.95 & 100.00 & 27.92 & 45.38 & 26.70 & 100.00 \\
\hline
\end{tabular}




\section{Table 2 \\ Comparisons of Selected Characteristics of (Non-)Backdated CEO Option Grants}

This table presents means and medians of selected characteristics of CEO stock option grants between 1999 and 2007. An option grant is assumed to be backdated when its value of $\mathrm{AR}(+1,+20)-\mathrm{AR}(-20,-2)$ is ranked among the top $10 \%$ of all sample grants, under the condition that its $\operatorname{AR}(-20,-2)$ is negative and $\operatorname{AR}(+1,+20)$ is positive. Firm size is proxied by market value of equity. Firm age is the difference between the first year in which the firm has data in Compustat and the option grant year. Growth opportunity is the market-to-book ratio, defined as the market value of assets (the book value of assets plus the market value of common stock less the sum of book value of common equity and balance sheet deferred taxes) divided by the book value of total assets. Profitability is measured by the return on assets, a ratio of EBIT (earnings before interest and tax) to total assets. Share ownership is calculated as shares owned over total shares outstanding. Option holdings is option grant value (Black-Scholes) divided by total compensation in the current year. Out-of-Moneyness is measured by the product of the aggregate number of (unexercised vested and unvested) option grants at the previous fiscal year end and the stock price difference between the previous fiscal year end and the month prior to the grant date, scaled by the (unexercised vested and unvested) in-the-money option value at the previous fiscal year end. Inside Director is the percentage of inside directors on the board. Gray Director is the percentage of gray outside directors on the board. CEO Hire Director is the percentage of outside board directors who are appointed after the incumbent CEO took office. CEO Chair is a dummy variable that is assigned to one if the CEO is also the chair of the board, and zero otherwise. Inside Director Compensation is a dummy variable that is assigned to one if at least one inside director serves on the compensation committee, and zero otherwise. Board size is the number of directors on the board. CEO tenure is the difference between the first year of company involvement and the option grant year. The GIM Index follows Gompers, Ishii, and Metrick (2003), and the Entrenchment Index follows Bebchuk, Cohen, and Ferrell (2009). Stock volatility is the standard deviation of daily stock prices in the option-granting month. Dispensable cash is defined as cash minus interest expenses, scaled by total assets.

\begin{tabular}{|c|c|c|c|c|c|c|c|c|}
\hline \multirow{2}{*}{ Variables } & & & \multicolumn{2}{|c|}{$\begin{array}{l}\text { Non-Backdated } \\
\text { Options }\end{array}$} & \multicolumn{2}{|c|}{ Backdated Options } & \multirow{2}{*}{$\begin{array}{c}\text { p-Value of } \\
\text { Test } \\
\text { for Diff. in } \\
\text { Means } \\
\text { (Distributions) }\end{array}$} & \multirow{2}{*}{$\begin{array}{l}\text { Number of } \\
\text { Observations }\end{array}$} \\
\hline & & & Mean & Median & Mean & Median & & \\
\hline \multirow{5}{*}{$\begin{array}{l}\text { Retention } \\
\text { Hypothesis }\end{array}$} & $\mathrm{H} 1$ & Firm Size & $12,656.24$ & $2,982.08$ & $8,048.66$ & $1,769.37$ & 0.0008 & 6,824 \\
\hline & & Firm Age & 28.68 & 24.00 & 23.06 & 16.00 & $\begin{array}{r}(0) \\
0 \\
(0)\end{array}$ & 6,830 \\
\hline & & Growth Opportunity & 1.95 & 1.53 & 2.19 & 1.67 & $\begin{array}{r}0.0001 \\
(0.0087)\end{array}$ & 6,824 \\
\hline & & Profitability & 0.09 & 0.08 & 0.07 & 0.07 & $\begin{array}{r}0.0001 \\
(0.0016)\end{array}$ & 6,824 \\
\hline & & $\begin{array}{l}\text { Share Ownership } \\
\text { (\%, excl. options) }\end{array}$ & 1.07 & 0.00 & 1.58 & 0.00 & $\begin{array}{r}0.0016 \\
(0)\end{array}$ & 6,701 \\
\hline \multirow[t]{2}{*}{$\begin{array}{l}\text { Incentive } \\
\text { Hypothesis }\end{array}$} & $\mathrm{H} 2$ & Option Holdings (\%) & 0.36 & 0.36 & 0.47 & 0.50 & $\begin{array}{r}0 \\
(0)\end{array}$ & 6,701 \\
\hline & & Out-of-Moneyness & -77.92 & 0.00 & 19.36 & 0.00 & $\begin{array}{r}0.2514 \\
(0)\end{array}$ & 6,440 \\
\hline \multirow{5}{*}{\multicolumn{2}{|c|}{$\begin{array}{l}\text { Agency } \\
\text { Hypothesis }\end{array}$}} & Inside Director (\%) & 0.17 & 0.14 & 0.19 & 0.17 & $\begin{array}{r}0 \\
(0)\end{array}$ & 6,277 \\
\hline & & Gray Director (\%) & 0.11 & 0.09 & 0.12 & 0.10 & $\begin{array}{r}0.3961 \\
(0.3376)\end{array}$ & 6,277 \\
\hline & & $\begin{array}{l}\text { CEO Hire Director } \\
(\%)\end{array}$ & 0.46 & 0.43 & 0.48 & 0.44 & 0.1542 & 6,277 \\
\hline & & CEO Chair & 0.63 & 1.00 & 0.59 & 1.00 & $\begin{array}{r}(0.2678) \\
0.1014 \\
(0.1014)\end{array}$ & 6,277 \\
\hline & & $\begin{array}{l}\text { Inside Director } \\
\text { Compensation }\end{array}$ & 0.01 & 0.00 & 0.01 & 0.00 & $\begin{array}{r}0.2077 \\
(0.2077)\end{array}$ & 6,277 \\
\hline
\end{tabular}




\begin{tabular}{|c|c|c|c|c|c|c|c|}
\hline & Board Size & 9.91 & 10.00 & 8.86 & 9.00 & $\begin{array}{r}0 \\
(0)\end{array}$ & 6,277 \\
\hline & CEO Tenure & 12.77 & 10.00 & 11.81 & 8.00 & $\begin{array}{l}0.0425 \\
(0.034)\end{array}$ & 6,758 \\
\hline & CEO Age & 55.82 & 56.00 & 54.58 & 55.00 & $\begin{array}{r}0.0001 \\
(0.0001)\end{array}$ & 6,542 \\
\hline & GIM Index & 9.51 & 9.00 & 8.92 & 9.00 & $\begin{array}{r}0 \\
(0)\end{array}$ & 6,830 \\
\hline & Entrenchment Index & 2.38 & 2.00 & 2.18 & 2.00 & $\begin{array}{r}0.0003 \\
(0.0004) \\
\end{array}$ & 6,830 \\
\hline \multirow[t]{2}{*}{ Control Attributes } & Stock Volatility & 1.29 & 0.88 & 1.64 & 1.12 & $\begin{array}{r}0 \\
(0)\end{array}$ & 6,807 \\
\hline & Dispensable Cash & 0.07 & 0.04 & 0.09 & 0.05 & $\begin{array}{r}0 \\
(0.0001)\end{array}$ & 6,824 \\
\hline
\end{tabular}


Table 3

\section{Determinants of Option Backdating}

This table provides coefficient estimates (marginal effects) for the probit models explaining the decision to backdate CEO stock option. The model specification is as follows, Prob $\left(\right.$ Backdate $\left._{i t}\right)=\alpha_{0}+\beta_{1} *$ Firm Size $_{i t-1}+\beta_{2} *$ Firm Age $_{i t}+\beta_{3} *$ Growth Opportunity $_{\text {it }-1}+\beta_{4} *$ Profitability $_{\text {it- } 1}+\beta_{5} *$ Share Ownership $_{\text {it }}+\beta_{6} *$ Option Holdings $_{\text {it }}+\beta_{7} *$ Out of-Moneyness ${ }_{i t}+\beta_{8} *$ Governance proxies $_{i t}+\beta_{9} *$ Stock Volatility ${ }_{i t}+\beta_{10} *$ Dispensable Cashi $i_{t-1}+\beta_{11} *$ Scheduled $_{i t}+\varepsilon_{i t}$. The dependent variable is assigned the value 1 for grants whose AR(+1,+20)-AR(-20,-2) is ranked among the top $10 \%$ of all sample grants, under the condition that AR(-20,-2) is negative and AR(+1,+20) is positive, and 0 otherwise. For the explanatory variables, firm size is proxied by log(1+market value of equity). Firm age is the difference between the first year in which the firm has data in Compustat and the option grant year. Growth opportunity is the market-to-book ratio (winsorized at the 1\% level), defined as the market value of assets (the book value of assets plus the market value of common stock less the sum of book value of common equity and balance sheet deferred taxes) divided by the book value of total assets. Profitability is measured by the return on assets, a ratio of EBIT (earnings before interest and tax) to total assets (winsorized at the 1\% level). Share ownership is calculated as shares owned over total shares outstanding (winsorized at the 1\% level). Option holdings is option grant value (Black-Scholes) divided by total compensation in the current year. Out-of-Moneyness is measured by the product of the aggregate number of (unexercised vested and unvested) option grants at the previous fiscal year end and the stock price difference between the previous fiscal year end and the month prior to the grant date, scaled by the (unexercised vested and unvested) in-the-money option value at the previous fiscal year end (winsorized at the 1\% level). Inside Director is the percentage of inside directors on the board. Gray Director is the percentage of gray outside directors on the board. CEO Hire Director is the percentage of outside board directors who are appointed after the incumbent CEO took office. CEO Chair is a dummy variable that is assigned to one if the CEO is also the chair of the board, and zero otherwise. Inside Director Compensation is a dummy variable that is assigned to one if at least one inside director serves on the compensation committee, and zero otherwise. Board size is the number of directors on the board. CEO tenure is the natural logarithm of the difference between the first year of company involvement and the option grant year. CEO age is standardized by the natural logarithm. The GIM Index follows Gompers, Ishii, and Metrick (2003), and the Entrenchment Index follows Bebchuk, Cohen, and Ferrell (2009). Stock volatility is the standard deviation of daily stock prices in the option-granting month (winsorized at the 1\% level). Dispensable cash is defined as cash minus interest expenses, scaled by total assets. A grant is defined as scheduled if it occurs within one day of the one-year anniversary of a prior grant or is followed by a grant dated within one day of the one-year anniversary of the grant in question. Industry fixed effects adopt 2-digit SIC codes. Standard deviations are clustered at the 2-digit SIC level. Fully standardized coefficients (both dependent and explanatory variables) are reported in brackets. Z-values are reported in parentheses, and the symbols *, **, and *** represent statistical significance at the $0.1,0.05$, and 0.01 levels, respectively.

\begin{tabular}{|c|c|c|c|c|c|c|c|c|c|}
\hline \multicolumn{2}{|c|}{ Explanatory Variables } & \multirow{2}{*}{$\frac{\text { Predicted Sign }}{-}$} & \multirow{2}{*}{$\frac{\text { Model } 1}{-0.038 * * *}$} & \multirow{2}{*}{$\frac{\text { Model } 2}{-0.031^{* * *}}$} & \multirow{2}{*}{$\frac{\text { Model } 3}{-0.040^{* * *}}$} & \multirow{2}{*}{$\frac{\text { Model } 4}{-0.040^{* * *}}$} & \multirow{2}{*}{$\frac{\text { Model } 5}{-0.030^{* * *}}$} & \multirow{2}{*}{$\frac{\text { Model } 6}{-0.040^{* * *}}$} & \multirow{2}{*}{$\frac{\text { Model } 7}{-0.028 * * *}$} \\
\hline Retention & Firm Size (t-1) & & & & & & & & \\
\hline \multirow[t]{11}{*}{ Hypothesis } & & & {$[-0.186]$} & {$[-0.152]$} & {$[-0.198]$} & {$[-0.202]$} & {$[-0.147]$} & {$[-0.185]$} & {$[-0.141]$} \\
\hline & & & $(-4.99)$ & $(-3.92)$ & $(-5.81)$ & $(-6.11)$ & $(-3.8)$ & $(-5.36)$ & $(-3.59)$ \\
\hline & Firm Age (t) & - & $-0.001 * * *$ & $-0.001 * * *$ & $-0.001 * *$ & $-0.001 * * *$ & $-0.001 * * *$ & & $-0.001 * * *$ \\
\hline & & & {$[-0.094]$} & {$[-0.091]$} & {$[-0.072]$} & {$[-0.08]$} & {$[-0.09]$} & & {$[-0.093]$} \\
\hline & & & $(-3.02)$ & $(-3.05)$ & $(-2.31)$ & $(-2.66)$ & $(-3.09)$ & & $(-3.13)$ \\
\hline & Growth Opportunity (t-1) & + & 0.004 & 0.003 & 0.004 & 0.004 & 0.003 & & $0.004 *$ \\
\hline & & & [0.039] & {$[0.033]$} & {$[0.042]$} & [0.042] & [0.031] & & [0.041] \\
\hline & & & $(1.57)$ & $(1.33)$ & $(1.53)$ & $(1.57)$ & (1.08) & & $(1.81)$ \\
\hline & Profitability (t-1) & - & $-0.101 * *$ & $-0.109 * * *$ & $-0.074 *$ & $-0.073 *$ & $-0.116^{* * *}$ & & $-0.089 * *$ \\
\hline & & & {$[-0.061]$} & {$[-0.066]$} & {$[-0.047]$} & {$[-0.046]$} & {$[-0.07]$} & & {$[-0.055]$} \\
\hline & & & $(-2.3)$ & $(-2.61)$ & $(-1.73)$ & $(-1.71)$ & $(-2.66)$ & & $(-2.51)$ \\
\hline
\end{tabular}




\begin{tabular}{|c|c|c|c|c|c|c|c|c|c|}
\hline & Technology (t) & + & $\begin{array}{l}0.027^{* *} \\
{[0.074]}\end{array}$ & $\begin{array}{l}0.023^{* *} \\
{[0.064]}\end{array}$ & $\begin{array}{l}0.026 * \\
{[0.073]}\end{array}$ & $\begin{array}{l}0.026^{*} \\
{[0.071]}\end{array}$ & $\begin{array}{l}0.023 * \\
{[0.063]}\end{array}$ & $\begin{array}{l}0.042^{* * *} \\
{[0.107]}\end{array}$ & \\
\hline & & & (2.19) & $(2.05)$ & (1.95) & (1.95) & $(1.77)$ & (4.28) & \\
\hline & Services $(t)$ & & 0.007 & 0.005 & 0.004 & 0.004 & 0.005 & & \\
\hline & & & {$[0.014]$} & {$[0.01]$} & {$[0.007]$} & {$[0.007]$} & {$[0.01]$} & & \\
\hline & & & $(0.58)$ & $(0.43)$ & $(0.32)$ & $(0.33)$ & $(0.47)$ & & \\
\hline & Trade (t) & & 0.006 & 0.006 & 0.002 & 0.002 & 0.003 & & \\
\hline & & & {$[0.013]$} & {$[0.012]$} & {$[0.005]$} & [0.004] & {$[0.006]$} & & \\
\hline & & & $(0.75)$ & $(0.67)$ & $(0.29)$ & $(0.23)$ & $(0.34)$ & & \\
\hline & Share Ownership (t) & - & 0.001 & 0.001 & 0.001 & 0.001 & 0.001 & 0.002 & 0.001 \\
\hline & & & {$[0.017]$} & {$[0.017]$} & {$[0.022]$} & {$[0.021]$} & {$[0.014]$} & {$[0.033]$} & {$[0.019]$} \\
\hline & & & $(0.84)$ & $(0.91)$ & $(1.05)$ & (1.03) & $(0.74)$ & (1.64) & $(0.97)$ \\
\hline Incentive & Option Holdings (t) & + & $0.022^{*}$ & 0.019 & $0.022^{*}$ & $0.021^{*}$ & 0.022 & & 0.009 \\
\hline Hypothesis & & & {$[0.047]$} & {$[0.04]$} & {$[0.046]$} & [0.045] & {$[0.047]$} & & {$[0.019]$} \\
\hline & & & $(1.88)$ & (1.5) & $(1.81)$ & $(1.77)$ & $(1.53)$ & & $(0.83)$ \\
\hline & Out-of-Moneyness (t) & + & $0.018^{* * *}$ & $0.018^{* * *}$ & $0.017^{* * *}$ & $0.017^{* * *}$ & $0.018^{* * *}$ & & $0.018^{* * *}$ \\
\hline & & & {$[0.13]$} & {$[0.128]$} & {$[0.121]$} & {$[0.121]$} & {$[0.122]$} & & {$[0.132]$} \\
\hline & & & $(5.49)$ & $(5.51)$ & $(5.28)$ & $(5.28)$ & $(5.12)$ & & $(5.75)$ \\
\hline Agency & Inside Director (t) & + & 0.005 & & & & & $0.086 * *$ & \\
\hline Hypothesis & & & {$[0.003]$} & & & & & {$[0.054]$} & \\
\hline & & & $(0.13)$ & & & & & (2.19) & \\
\hline & Gray Director (t) & + & -0.006 & & & & & 0.029 & \\
\hline & & & {$[-0.006]$} & & & & & [0.025] & \\
\hline & & & $(-0.24)$ & & & & & $(0.98)$ & \\
\hline & CEO Hire Director (t) & + & 0.011 & & & & & 0.016 & \\
\hline & & & {$[0.025]$} & & & & & [0.035] & \\
\hline & & & $(1.13)$ & & & & & $(1.47)$ & \\
\hline & CEO Chair (t) & + & -0.000 & & & & & 0.002 & \\
\hline & & & {$[-0.001]$} & & & & & [0.007] & \\
\hline & & & $(-0.03)$ & & & & & $(0.3)$ & \\
\hline & Inside Director & + & 0.008 & & & & & 0.010 & \\
\hline & Compensation (t) & & {$[0.004]$} & & & & & {$[0.005]$} & \\
\hline & & & $(0.17)$ & & & & & $(0.21)$ & \\
\hline & Board Size (t) & + & & $-0.003 * * *$ & & & $-0.003 * * *$ & & $-0.002 *$ \\
\hline & & & & {$[-0.069]$} & & & {$[-0.066]$} & & {$[-0.041]$} \\
\hline & & & & $(-3.36)$ & & & $(-3.15)$ & & $(-1.68)$ \\
\hline & CEO Tenure (t) & + & $-0.006^{*}$ & -0.004 & $-0.006 *$ & $-0.006 *$ & & $-0.011 * * *$ & -0.003 \\
\hline & & & {$[-0.039]$} & {$[-0.027]$} & {$[-0.037]$} & {$[-0.039]$} & & {$[-0.067]$} & {$[-0.021]$} \\
\hline & & & $(-1.82)$ & $(-1.21)$ & $(-1.69)$ & $(-1.81)$ & & $(-3.29)$ & $(-0.93)$ \\
\hline & CEO Age & + & & & & & -0.013 & & \\
\hline
\end{tabular}




\begin{tabular}{|c|c|c|c|c|c|c|c|c|c|}
\hline & & & & & & & \multicolumn{3}{|l|}{$\begin{array}{l}{[-0.012]} \\
(-0.52)\end{array}$} \\
\hline & GIM Index (t) & + & & & \multicolumn{2}{|l|}{$\begin{array}{l}-0.002^{* *} \\
{[-0.036]} \\
(-2.36)\end{array}$} & & & \\
\hline & Entrenchment Index (t) & + & & & & $\begin{array}{l}-0.005^{*} \\
{[-0.042]} \\
(-1.75)\end{array}$ & & & \\
\hline Control & Stock Volatility (t) & + & $0.016^{* * *}$ & $0.015^{* * *}$ & $0.015^{* * *}$ & $0.015^{* * *}$ & $0.015^{* * *}$ & $0.023^{* * *}$ & $0.013^{* * *}$ \\
\hline \multirow[t]{14}{*}{ Attributes } & & & {$[0.133]$} & {$[0.129]$} & {$[0.122]$} & {$[0.122]$} & {$[0.128]$} & {$[0.177]$} & {$[0.114]$} \\
\hline & & & (5.66) & (5.43) & $(5.41)$ & $(5.41)$ & $(5.4)$ & $(8.67)$ & $(4.77)$ \\
\hline & Dispensable Cash (t-1) & - & 0.001 & -0.002 & 0.013 & 0.012 & -0.005 & & 0.005 \\
\hline & & & {$[0.001]$} & {$[-0.001]$} & {$[0.01]$} & {$[0.01]$} & {$[-0.004]$} & & {$[0.004]$} \\
\hline & & & $(0.03)$ & $(-0.06)$ & $(0.55)$ & $(0.51)$ & $(-0.17)$ & & $(0.19)$ \\
\hline & Scheduled (t) & - & -0.003 & -0.003 & -0.003 & -0.003 & -0.003 & -0.013 & -0.002 \\
\hline & & & {$[-0.012]$} & {$[-0.01]$} & {$[-0.011]$} & {$[-0.012]$} & {$[-0.012]$} & {$[-0.042]$} & {$[-0.006]$} \\
\hline & & & $(-0.44)$ & $(-0.41)$ & $(-0.4)$ & $(-0.42)$ & $(-0.47)$ & $(-1.59)$ & $(-0.23)$ \\
\hline & Post-SOX (t) & - & $-0.056 * * *$ & $-0.056 * * *$ & $-0.055^{* * *}$ & $-0.054 * * *$ & $-0.056 * * *$ & & \\
\hline & & & {$[-0.209]$} & {$[-0.211]$} & {$[-0.202]$} & {$[-0.201]$} & {$[-0.209]$} & & \\
\hline & & & $(-7.06)$ & $(-7.59)$ & $(-7.33)$ & $(-7.09)$ & $(-7.67)$ & & \\
\hline & Post-Scandal (t) & - & $-0.051 * * *$ & $-0.052 * * *$ & $-0.051 * * *$ & $-0.051 * * *$ & $-0.051 * * *$ & & \\
\hline & & & {$[-0.189]$} & {$[-0.196]$} & {$[-0.19]$} & {$[-0.188]$} & {$[-0.19]$} & & \\
\hline & & & $(-5.71)$ & $(-5.7)$ & $(-5.28)$ & $(-5.23)$ & $(-5.05)$ & & \\
\hline Industry FE & & & No & No & No & No & No & No & Yes \\
\hline Year FE & & & No & No & No & No & No & No & Yes \\
\hline Pseudo $\mathrm{R}^{2}$ & & & 0.0935 & 0.0947 & 0.0878 & 0.0881 & 0.093 & 0.0499 & 0.1157 \\
\hline \# of obs. & & & 5,900 & 5,900 & 6,360 & 6,360 & 5,786 & 6,131 & 5,799 \\
\hline
\end{tabular}




\section{Table 4 \\ Option Backdating and Subsequent Accounting Performance}

This table shows the maximum likelihood coefficient estimates of the treatment-effects models on how the backdating of CEO stock option grants might influence subsequent accounting performance. The model specification is as follows, Profitability $i t+1=\alpha_{0}+\beta_{1}{ }^{*}$ Firm Size $e_{i t}+\beta_{2}{ }^{*}$ Profitability $_{i t}+\beta_{3}{ }^{*}$ Backdate $_{i t}+\varepsilon_{i t}$. The dependent variable is forward return on assets, a ratio of EBIT (earnings before interest and tax) to total assets in year $(\mathrm{t}+1)$. For the explanatory variables, the option backdating variable is a dummy variable and made according to the rule,

$$
\text { Backdate }_{i t}=\left\{\begin{array}{c}
1, \text { if Backdate } \\
\text { it } \\
0, \text { otherwise }
\end{array}\right.
$$

where Backdate ${ }_{i t}=f\left(\right.$ Firm Size $_{i t-1}$, Firm Age ${ }_{i t}$, Growth Opportunity ${ }_{i-1}$, Profitability $y_{i-1}$, Share Ownership ${ }_{i t}$, Option Holdings $_{i t}$, Out-of-Moneyness ${ }_{i t}$, Governance proxies ${ }_{i t}$, Stock Volatility ${ }_{i t}$, Dispensable Cash $_{i t-1}$, Scheduled $\left.{ }_{i t}\right)$. Firm size is proxied by $\log (1+$ market value of equity). Firm age is the difference between the first year in which the firm has data in Compustat and the option grant year. Growth opportunity is the market-to-book ratio (winsorized at the 1\% level), defined as the market value of assets (the book value of assets plus the market value of common stock less the sum of book value of common equity and balance sheet deferred taxes) divided by the book value of total assets. Profitability is measured by the return on assets, a ratio of EBIT (earnings before interest and tax) to total assets (winsorized at the $1 \%$ level). Share ownership is calculated as shares owned over total shares outstanding (winsorized at the $1 \%$ level). Option holdings is option grant value (Black-Scholes) divided by total compensation in the current year. Out-of-Moneyness is measured by the product of the aggregate number of (unexercised vested and unvested) option grants at the previous fiscal year end and the stock price difference between the previous fiscal year end and the month prior to the grant date, scaled by the (unexercised vested and unvested) in-the-money option value at the previous fiscal year end (winsorized at the $10 \%$ level). Inside Director is the percentage of inside directors on the board. Gray Director is the percentage of gray outside directors on the board. CEO Hire Director is the percentage of outside board directors who are appointed after the incumbent CEO took office. CEO Chair is a dummy variable that is assigned to one if the CEO is also the chair of the board, and zero otherwise. Inside Director Compensation is a dummy variable that is assigned to one if at least one inside director serves on the compensation committee, and zero otherwise. Board size is the number of directors on the board. CEO tenure is the natural logarithm of the difference between the first year of company involvement and the option grant year. CEO age is standardized by the natural logarithm. The GIM Index follows Gompers, Ishii, and Metrick (2003), and the Entrenchment Index follows Bebchuk, Cohen, and Ferrell (2009). Stock volatility is the standard deviation of daily stock prices in the option-granting month (winsorized at the $1 \%$ level). Dispensable cash is defined as cash minus interest expenses, scaled by total assets. A grant is defined as scheduled if it occurs within one day of the one-year anniversary of a prior grant or is followed by a grant dated within one day of the one-year anniversary of the grant in question. All proxies for profitability are winsorized at the $1 \%$ level. Industry fixed effects adopt 2-digit SIC codes. Z-values are reported in parentheses, and the symbols *, **, and *** represent statistical significance at the 0.1 , 0.05 , and 0.01 levels, respectively.

\begin{tabular}{|c|c|c|c|c|c|c|}
\hline \multicolumn{2}{|c|}{ Explanatory Variables } & Model 1 & Model 2 & Model 3 & Model 4 & Model 5 \\
\hline \multicolumn{7}{|c|}{ Control Variables: } \\
\hline \multicolumn{2}{|r|}{ Firm Size (t) } & $\begin{array}{l}0.008^{* * *} \\
(8.19)\end{array}$ & $\begin{array}{l}0.008^{* * *} \\
(8.2)\end{array}$ & $\begin{array}{l}0.008^{* * *} \\
(8.76)\end{array}$ & $\begin{array}{l}0.008 * * * \\
(8.78)\end{array}$ & $\begin{array}{l}0.008^{* * *} \\
(8.46)\end{array}$ \\
\hline \multirow{3}{*}{\multicolumn{2}{|c|}{$\begin{array}{l}\text { Option } \\
\text { Backdating }\end{array}$}} & $\begin{array}{l}0.796 * * * \\
(95.03)\end{array}$ & $\begin{array}{l}0.796 * * * \\
(95.03)\end{array}$ & $\begin{array}{l}0.795^{* * *} \\
(101.2)\end{array}$ & $\begin{array}{l}0.795^{* * *} \\
(101.2)\end{array}$ & $\begin{array}{l}0.795^{* * *} \\
(94.21)\end{array}$ \\
\hline & & -0.005 & -0.004 & -0.004 & -0.004 & -0.004 \\
\hline & & $(-0.9)$ & $(-0.86)$ & $(-0.87)$ & $(-0.77)$ & $(-0.83)$ \\
\hline \multicolumn{7}{|c|}{ Selection Variables: } \\
\hline \multirow[t]{5}{*}{$\begin{array}{l}\text { Retention } \\
\text { Hypothesis }\end{array}$} & Firm Size (t-1) & $\begin{array}{l}-0.343^{* * *} \\
(-7.15)\end{array}$ & $\begin{array}{l}-0.310^{* * *} \\
(-5.84)\end{array}$ & $\begin{array}{l}-0.351^{* * *} \\
(-7.85)\end{array}$ & $\begin{array}{l}-0.359 * * * \\
(-8)\end{array}$ & $\begin{array}{l}-0.299 * * * \\
(-5.58)\end{array}$ \\
\hline & Firm Age (t) & $\begin{array}{l}-0.005^{* * *} \\
(-2.65)\end{array}$ & $\begin{array}{l}-0.005^{* * *} \\
(-2.63)\end{array}$ & $\begin{array}{l}-0.003 * \\
(-1.78)\end{array}$ & $\begin{array}{l}-0.004 * * \\
(-2.18)\end{array}$ & $\begin{array}{l}-0.005^{* *} \\
(-2.5)\end{array}$ \\
\hline & Growth Opportunity (t-1) & $\begin{array}{l}0.054 * * \\
(2.13)\end{array}$ & $\begin{array}{l}0.048^{*} \\
(1.87)\end{array}$ & $\begin{array}{l}0.052 * * \\
(2.22)\end{array}$ & $\begin{array}{l}0.051^{* *} \\
(2.19)\end{array}$ & $\begin{array}{l}0.046^{*} \\
(1.78)\end{array}$ \\
\hline & Profitability (t-1) & $\begin{array}{l}-0.860 * * \\
(-2.5)\end{array}$ & $\begin{array}{l}-0.868 * * \\
(-2.53)\end{array}$ & $\begin{array}{l}-0.682 * * \\
(-2.18)\end{array}$ & $\begin{array}{l}-0.665^{* *} \\
(-2.13)\end{array}$ & $\begin{array}{l}-0.930 * * * \\
(-2.69)\end{array}$ \\
\hline & Share Ownership (t) & $\begin{array}{l}0.007 \\
(0.86)\end{array}$ & $\begin{array}{l}0.007 \\
(0.96)\end{array}$ & $\begin{array}{l}0.010 \\
(1.28)\end{array}$ & $\begin{array}{l}0.009 \\
(1.2)\end{array}$ & $\begin{array}{l}0.007 \\
(0.97)\end{array}$ \\
\hline
\end{tabular}




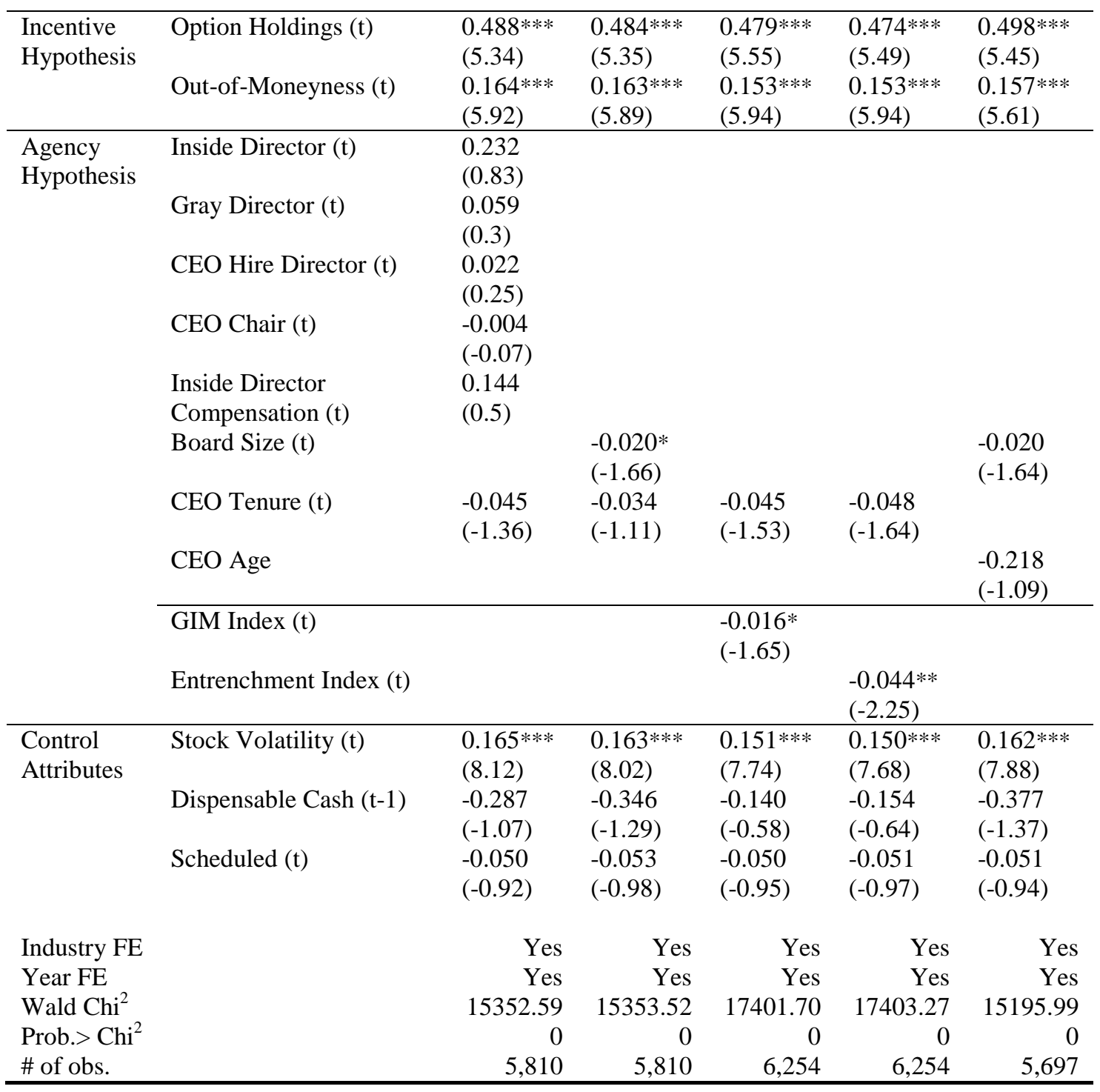




\section{Table 5 \\ Option Backdating and Calendar-Time Fama-French Four-Factor Model Abnormal Returns}

This table reports calendar-time abnormal returns using the Fama-French four-factor model as follows,

$$
R_{i t}-R_{t}^{f}=\alpha_{i}+\beta_{i} *\left(R_{t}^{\operatorname{mar}}-R_{t}^{f}\right)+\gamma_{i} * S M B_{t}+\delta_{i} * H M L_{t}+\lambda_{i} * W M L_{t}+\varepsilon_{i t}
$$

where $R_{i}$ is the equal-weighted portfolio i return, $R^{f}$ is the risk-free rate (one month Treasury bill rate), $R^{\text {mar }}$ is the CRSP value-weighted market portfolio return, SMB is the return of a portfolio of small stocks minus the return of a portfolio of large stocks, HML is the return of a portfolio of high book-to-market stocks minus the return of a portfolio of low book-to-market stocks, and WML is the return of a portfolio of high momentum stocks (winner) minus the return of a portfolio of low momentum stocks (loser). An option grant is assumed to be backdated when its value of $\mathrm{AR}(+1,+20)$-AR(-20,-2) is ranked among the top $10 \%$ of all sample grants, under the condition that its AR(-20,-2) is negative and AR(+1,+20) is positive. Each month we form portfolios consisting of all grants (grantbased portfolio) that have been issued and of all firms (firm-based portfolio) that have issued a grant within the last $n$ years (where $n$ is the length of the holding period). Portfolio returns are equally weighted. Abnormal returns are given by the intercept when excess portfolio returns are regressed on the four Fama-French factors. T-statistics are in parentheses, and the symbols $* * *$, and $* * *$ represent statistical significance at the $0.1,0.05$, and 0.01 levels, respectively.

\begin{tabular}{|c|c|c|c|c|c|c|}
\hline \multirow{2}{*}{ Abnormal Returns } & \multicolumn{3}{|c|}{ Grant-Based Portfolio } & \multicolumn{3}{|c|}{ Firm-Based Portfolio } \\
\hline & 1-Year & 2-Year & 3-Year & 1-Year & 2-Year & 3-Year \\
\hline Non-Backdated Options (1) & $\begin{array}{l}0.003^{*} \\
(1.97)\end{array}$ & $\begin{array}{l}0.003 * * \\
(2.35)\end{array}$ & $\begin{array}{l}0.010^{*} \\
(1.66)\end{array}$ & $\begin{array}{l}0.003^{*} \\
(1.83)\end{array}$ & $\begin{array}{l}0.003^{* *} \\
(2.63)\end{array}$ & $\begin{array}{l}0.002^{* * *} \\
(2.84)\end{array}$ \\
\hline Backdated Options (2) & $\begin{array}{l}0.004 \\
(1.16)\end{array}$ & $\begin{array}{l}0.005^{*} \\
(1.89)\end{array}$ & $\begin{array}{l}0.009 \\
(1.36)\end{array}$ & $\begin{array}{l}0.004 \\
(1.32)\end{array}$ & $\begin{array}{l}0.004 * \\
(1.79)\end{array}$ & $\begin{array}{l}0.002 \\
(1.38)\end{array}$ \\
\hline $\begin{array}{l}\text { Excess Abnormal Return } \\
\text { (2)-(1) }\end{array}$ & $\begin{array}{l}0.000 \\
(0.14)\end{array}$ & $\begin{array}{l}0.002 \\
(0.81)\end{array}$ & $\begin{array}{l}-0.001 \\
(-0.11)\end{array}$ & $\begin{array}{l}0.001 \\
(0.34)\end{array}$ & $\begin{array}{l}0.002 \\
(0.64)\end{array}$ & $\begin{array}{l}-0.000 \\
(-0.07)\end{array}$ \\
\hline
\end{tabular}

